\title{
Marcusenius desertus sp. nov. (Teleostei: Mormyridae), a mormyrid fish from the Namib desert
}

\author{
LB Kramer ${ }^{1 *}$, FH van der Bank ${ }^{2}$ and M Wink ${ }^{3}$ \\ ${ }^{1}$ Zoological Institute, University of Regensburg, Regensburg, Germany \\ ${ }^{2}$ African Centre for DNA Barcoding, Department of Zoology, University of Johannesburg, Johannesburg, South Africa \\ ${ }^{3}$ Institute of Pharmacy and Molecular Biotechnology, Heidelberg University, Heidelberg, Germany \\ * Corresponding author, e-mail: bernd.kramer@ur.de
}

\begin{abstract}
We critically compared Marcusenius specimens from the mouth of the Cunene River on the Namibia/Angola border, a harsh desert environment on the Atlantic Ocean coast virtually devoid of aerial insects with aquatic larvae which are an important food item, with Marcusenius multisquamatus Kramer \& Wink, 2013 from the escarpment region of that same river, in a relatively rich and productive subtropical savannah environment. River mouth specimens were differentiated in morphology and electric organ discharges, as determined by ANOVA/MANOVA comparisons, principal component and discriminant analyses on morphological and electrophysiological characters, and genetics, including sequences of the mitochondrial cytochrome $b$ gene, indicating reproductive isolation. Specimens from the river mouth differed from M. multisquamatus, their closest relatives, by having a shorter snout, a smaller eye diameter, and smaller nares separation. River mouth specimens were also differentiated from other, increasingly less-close relatives, such as M. altisambesi Kramer et al., 2007 from the Okavango River, Botswana, and from M. krameri Maake et al., 2014 from the Limpopo System, South Africa. We therefore designate the new species Marcusenius desertus sp. nov. for the Cunene River mouth population.
\end{abstract}

http://zoobank.org/urn:Isid:zoobank.org:pub:C2DE6B82-85FD-41DE-931B-A486508379FC

Online supplementary material: A list of other fish species collected from the Cunene mouth and output from the PCA testing for correlation between the morphological characteristics of four fish species are available online in Supplementary Tables S1 and S2 at http://dx.doi.org/10.2989/16085914.2015.1137855.

Keywords: ecology, electric organ discharges, genetic differentiation, morphology, phylogeography, speciation

Introduction

With about 47 species, the genus Marcusenius Gill, 1862 is one of the largest within the largest freshwater fish family endemic to Africa, the Mormyridae or snoutfish (Eschmeyer et al. n.d.). All of its members that have been studied generate and perceive weak electric currents with specialised electric organs for electrolocation and electrocommunication (Bullock and Heiligenberg 1986; Kramer 1990; Moller 1995; Kramer 1996; Bullock et al. 2005; Wiltschko and Kramer 2009).

Despite its size, new members of the genus Marcusenius continue to be described, for example, Kramer et al. (2007), Kramer (2013a) and Maake et al. (2014). Among them is M. multisquamatus, the bulldog fish endemic to the Cunene River (Kramer and Wink 2013). The Cunene (or Kunene) River arises in the Bié Highlands in Angola and runs southward parallel to the Cubango River, the headwater of the Okavango, for hundreds of kilometres, but turns sharply west in its lower course, where it forms the border between Angola and Namibia for its final $300 \mathrm{~km}$ before discharging into the Atlantic Ocean. The type region for $M$. multisquamatus is above Epupa Falls at $600 \mathrm{~m}$ elevation on the escarpment of the African continent which faces the Atlantic Ocean. Little is known of the Cunene below that point. The Cunene River is assumed to have historical connections with the Okavango System, especially through its headwaters in Angola (Moore and Larkin 2001). This would explain the high similarity index of its fish fauna with that of the Okavango (Skelton 1994).

When one of us (FHvdB), on a separate expedition to Namibia's northernmost part of the Skeleton Coast in December 2009, discovered bulldog fish at the river mouth of the Cunene, we became interested in comparing these with the escarpment specimens. The Cunene River mouth region offers an extremely harsh, cold and storm-swept desert environment. There were no trees and very little higher plant life, excepting occasional reed beds bordering the river banks, which were of either bare rock or sand, and mostly difficult to climb. The only birds observed, disregarding sea birds seen at the shore, were whitebreasted cormorants Phalacrocorax carbo nesting on the ledges of cliffs at the river banks, a small flock of pied crows Corvus albus and a mountain chat Oenanthe monticola attracted to our 
campsite. This was in stark contrast to the pleasant and warm escarpment environment at Epupa and Ruacana Falls, surrounded by bush savannah, where there are palms and other trees, diverse bushes and other plants bordering the river banks, and a birdlife rich both in species and numbers. For bulldog fish, the food spectrum is therefore assumed to differ between the Cunene River mouth and the escarpment at Epupa Falls and above. Ecological differences such as these may support their differentiation.

The bulldog specimens obtained earlier from the Cunene River mouth had been fixed in $96 \%$ alcohol, and proved differentiated from type region $M$. multisquamatus in both genetics and morphology (Kramer and Wink 2013). The alcohol fixation was good for DNA studies, but perhaps less so for morphology because of the effects of strong and sudden dehydration on the fish body. Therefore, and because electric organ discharges (EODs) had not been recorded from river mouth specimens, we collected another, larger sample of river mouth specimens, recorded their EODs on site immediately after capture, took DNA tissue samples, and killed and fixed specimens according to our usual procedure (Kramer and Wink 2013: 2331). We hoped this new sample would enable us to draw firm conclusions about the systematic state of the Cunene River mouth bulldog.

In combination with other characters, EODs of mormyrids have been used successfully to clarify systematic questions by several authors in addition to the studies cited above, e.g. Crawford and Hopkins (1989); Sullivan et al. (2002); Arnegard and Hopkins (2003); Lavoué et al. (2004); Arnegard et al. (2006); Feulner et al. (2006, 2007); Moritz et al. (2009) and Arnegard et al. (2010). DNA studies using nucleotide sequences of the mitochondrial marker gene cytochrome $b$ and ISSR-genomic fingerprint analyses have already greatly contributed to resolving the status of mormyrids for more tropical African regions, e.g. Agnèse and Bigorne (1992); Lavoué et al. (2000); Sullivan et al. (2000), Sullivan et al. (2002); Lavoué and Sullivan (2004); Sullivan et al. (2004); Feulner et al. (2006, 2007); Lavoué (2012) and Lavoué and Sullivan (2014). For southern Africa, the studies by van der Bank and Kramer (1996), Kramer and van der Bank (2000), Kramer et al. (2004), Kramer et al. (2007), Kramer and Swartz (2010) and Maake et al. (2014) are examples.

In order to ascertain unambiguously the status of the Cunene River mormyrids, we increased the number of samples from the Cunene River mouth, to strengthen our database for additional DNA, EOD and morphology studies at higher resolution.

\section{Materials and methods}

We studied 84 fish from three rivers: the lower section of the Cunene River where it forms the border between Namibia and Angola (localities 1-3), the Okavango River where it starts to fan out to form a huge inland delta in Botswana (locality 4), and the Mokolo River, a southern tributary to the Limpopo River in South Africa (locality 5, Figure 1). The Cunene River is inhabited by Marcusenius multisquamatus Kramer \& Wink, 2013, the Okavango by M. altisambesi Kramer, Skelton, van der Bank \& Wink,
2007, and the Limpopo System by the widespread $M$. pongolensis (Fowler, 1934), whereas in the Mokolo River and three other southern tributaries of the Limpopo the recently described species $M$. krameri (Maake, Gon \& Swartz, 2014) was observed (Figure 2).

We combined $M$. multisquamatus samples from localities 1 and 2 from the escarpment at 600-800 m elevation, and compared them to samples from the Cunene River mouth on the Atlantic Ocean coast (locality 3), using morphology, molecular genetics and EODs. We studied the differentiation between the two Cunene samples, as compared to the differentiation from the other two samples, in order to assess better the systematic relationship between the former.

At the Cunene River mouth we caught most fish in gillnets of 40 and $90 \mathrm{~mm}$ stretched mesh, along with other fish species using also other fishing methods (see Table S1, available online).

\section{Fish morphology}

At least 13 measurements (see Figure 3) and four counts were taken on morphological characters. As already described in Kramer and Wink (2013), the following abbreviations and definitions were used: PDL, predorsal length: distance tip of snout (excluding mental lobe or chin) to dorsal fin origin; PAL, preanal length: distance tip of snout to anal fin origin; LD, dorsal fin length; LA, anal fin length; $\mathrm{pD}$, distance dorsal fin origin to end of caudal peduncle; CPL, length of caudal peduncle (end of anal fin base to midbase of caudal fin); CPD, depth of caudal peduncle: the least vertical distance across the caudal peduncle; LS, length of snout: distance from tip of snout to posterior orbital rim of eye (LSo), from tip of snout to centre of eye (LSc); HL, head length: distance tip of the snout to furthest bony edge of the operculum; $\mathrm{Na}$, distance between the pair of nares on one side (from centre to centre); OD, eye diameter: defined by orbital rims; LPF, length of pectoral fins; PPF, distance between anterior base of pectoral fin to anterior base of pelvic fin; SL, standard length: distance tip of snout to midbase of caudal fin; BD, body depth: the greatest vertical distance across the body; TL, total length: distance tip of snout to end of caudal fin; $n D$, number of dorsal fin rays; $n A$, number of anal fin rays; SPc, number of scales around caudal peduncle; SLS, number of scales in linear series along the lateral line row, as detailed in Skelton (2001: 67); SLS range of accuracy, \pm 2 counts.

As detailed in Kramer and Wink (2013) and updated here, abbreviations used to represent institutions and collections cited followed Fricke and Eschmeyer (n.d.). Collection acronyms used in the present paper were: SAIAB, South African Institute for Aquatic Biodiversity, Grahamstown, South Africa; ZSM, Zoologische Staatssammlung München, Germany; ANSP, Academy of Natural Sciences, Philadelphia, Pennsylvania, USA; MRAC, Musée Royal de l'Afrique Centrale, Tervuren, Belgium; IPMB, Institute of Pharmacy and Molecular Biotechnology, Heidelberg University, Germany. Specimens examined were identified using dichotomous keys in Bell-Cross and Minshull (1988), Skelton (1993, 2001), and Maake et al. (2014) which are considered effective for fish populations occurring in southern Africa. 


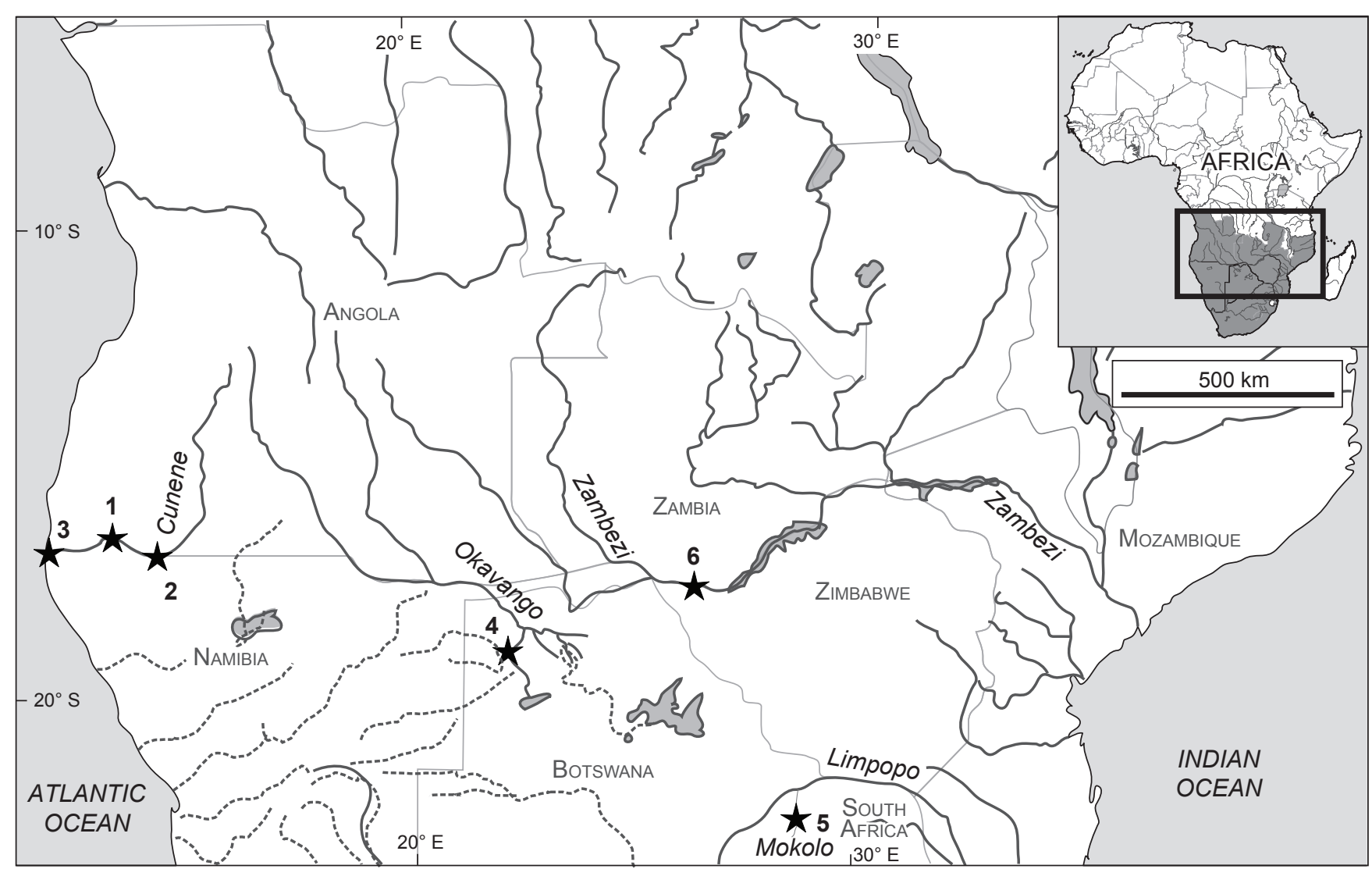

Figure 1: Map of part of southern-central Africa, showing localities of bulldog fish samples examined. (1) Type locality of Marcusenius multisquamatus, Cunene River just above Epupa Falls; (2) Cunene River, Ruacana Falls; (3) Cunene River mouth; (4) Okavango River; (5) Mokolo River, which flows northwards into the Limpopo; (6) Victoria Falls

\section{Electric organ discharges (EODs)}

This section is slightly modified from the one in Kramer and Wink (2013) to suit the present study. Electric organ discharges were recorded in the field immediately after capture in a 37-litre plastic aquarium filled with river water where the fish was collected. Conductivity changes possibly affecting EOD were, therefore, excluded.

Temperature $\left( \pm 0.1^{\circ} \mathrm{C}\right)$ and water conductivity $\left( \pm 1 \mu \mathrm{S} \mathrm{cm}^{-1}\right)$ were constantly monitored using an electronic apparatus (LF92 by Wissenschaftlich-Technische Werkstätten, WTW, Germany). Fish were placed between a pair of carbon rod electrodes that were connected to a differential amplifier with a variable gain (up to $\times 10 ; 0.2 \mathrm{~Hz} \ldots 100 \mathrm{kHz}$; filter slopes, $-3 \mathrm{~dB}$ per octave; electronics workshop, Biology Department, University of Regensburg). Amplifier output was recorded with a digital storage oscilloscope (up to at least $10 \mathrm{MHz}$ conversion rate, amplitude resolution 8 bit, 512 points per trace in the field, replaced by a $100 \mathrm{MHz} / 9 \mathrm{bit} / 10000$ points per sweep oscilloscope from 2003 on), and data were numerically transferred onto the hard disk of a computer via digital interface. Usually eight traces per fish were recorded. Field equipment was battery-operated.

Custom-designed computer programs were used for analysis of EODs (programmed using a software package for signal analysis, Famos v3.1 to v6.3 by imc company,
Berlin). When appropriate, EOD duration was corrected to $25{ }^{\circ} \mathrm{C}$ using a $Q_{10}$ value of 1.5 (Kramer and Westby 1985) before data analysis.

Definition of EOD waveform variables (compare with Figure 4): Pamp, peak amplitude of positive $P$ phase (i.e. from baseline to peak, which was set equal to 1 by definition); Namp, peak amplitude of negative $\mathrm{N}$ phase of EOD re: Pamp $=1$; Pdur, Ndur, durations of $P$ phase and $N$ phase; $P N s e p$, separation (or interval) between the peaks of the $\mathrm{P}$ and $\mathrm{N}$ phases; Parea, Narea, areas under the $\mathrm{P}$ and $\mathrm{N}$ phases. Durations in microseconds; amplitudes in relative volts (re: P-phase amplitude $=1$ ). Area measures, dimension ( $\mathrm{V} \times$ microseconds). Because of the asymptotic start and termination of an EOD, Pdur started at $+5 \%$ of Pamp, and Ndur ended at $-5 \%$ of Pamp. This threshold criterion was also used for Parea and Narea estimations. The EOD characters analysed are detailed in Figure 4.

As detailed in Kramer and Wink (2013), subsequent to EOD recording, fish were killed by an overdose of the anaesthetic 2-phenoxy-ethanol; SL, standard length, was determined using vernier callipers and the fish were fixed in $10 \%$ formalin for morphological studies. Fish were sexed by using the kink criterion of the anal fin base (a kink is absent in females and juvenile males, as confirmed histologically for certain bulldog fish and described in Kramer [1997] and Kramer et al. [2007]). 


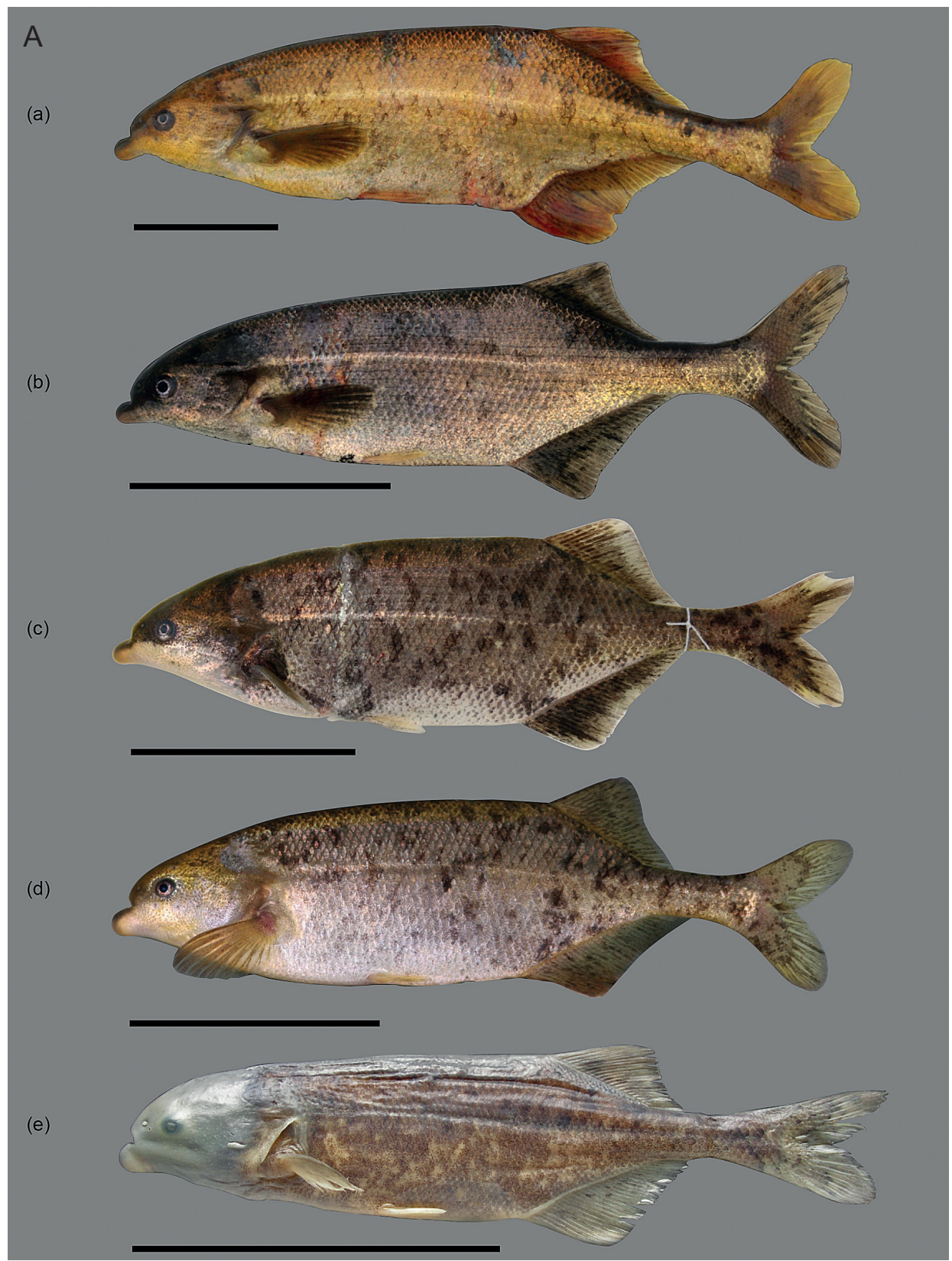

B
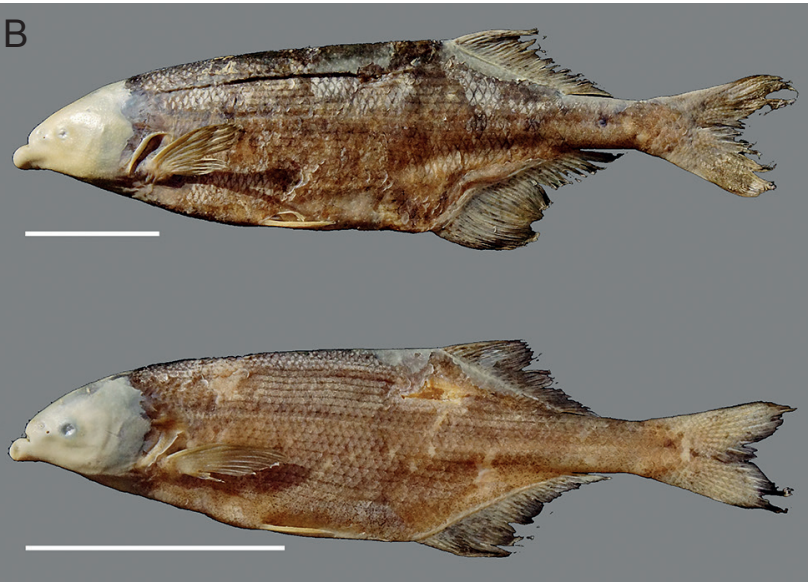

Figure 2A, B: (A) Photographs of the fish studied (bar $=5 \mathrm{~cm}$ ). (a) Marcusenius desertus sp. nov. male, ZSM 43802, holotype, SL $19.6 \mathrm{~cm}$, coll. FH van der Bank, S Voges, B Kramer, Cunene River mouth, coll. and photographed on 10 Oct 2012. (b) Marcusenius desertus sp. nov. female, ZSM 43803, paratype, field no. 6, SL $12.3 \mathrm{~cm}$, coll. FH van der Bank, S Voges, B Kramer, Cunene River mouth, coll. and photographed on 11 Oct 2012. (c) Marcusenius multisquamatus, SAIAB 7875, coll. E Swartz, B Kramer, coll. and photographed on 19 Aug 2006, Cunene River below Ruacana Falls, specimen RUAC01, SL $15.4 \mathrm{~cm}$. (d) Marcusenius altisambesi, coll. FH van der Bank, B Kramer, 11/12 Aug 2004, Okavango River, live fish of SL $13 \mathrm{~cm}$ photographed 20 Apr 2006 in aquarium. (e) Marcusenius krameri, Mokolo River, SAIAB 88845, field no. Mogol25, coll. A Hoffman, B Kramer, 20 Oct 2008, $\mathrm{SL} 9.2 \mathrm{~cm}$. (B) The two M. desertus sp. nov. specimens shown in (A) fixed 


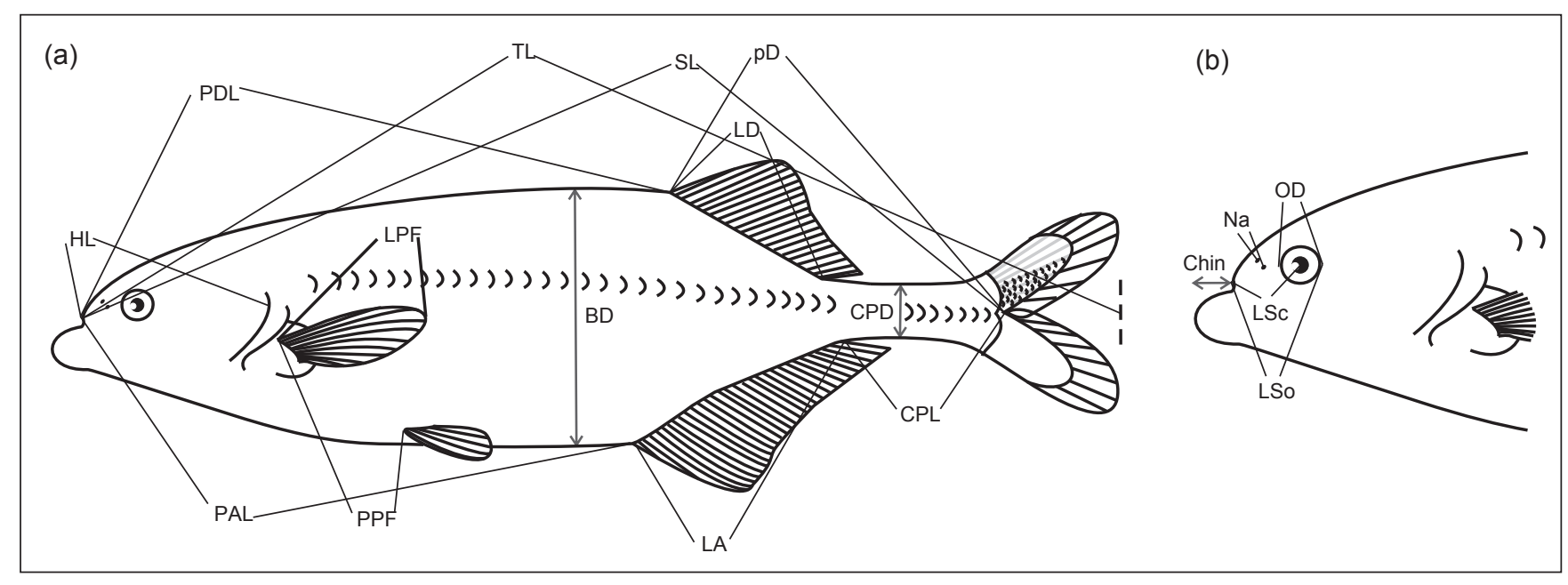

Figure 3: Explanation of the morphological characters studied. (a) Whole fish, (b) head detail. Measurements taken using vernier callipers, a Zeiss stereo loupe (magnification $4 \times$ at $30 \mathrm{~cm}$ working distance), or a Zeiss zoom stereomicroscope, as required. For abbreviations, see text in Materials and Methods. From Kramer and Wink (2013)

\section{Statistical analysis}

The same principal component analysis (PCA) and discriminant analysis (DA) procedures on correlations among anatomical and electrical characters as already described in Kramer and Wink (2013) were used, in order to test for differences in body shape or EOD waveform among the samples of different origins. Analyses of variance (ANOVA) were performed to test hypotheses of no difference between samples for each character individually. Multivariate analyses of variance (MANOVA) were performed in order not to overestimate differentiation when examining the hypothesis of no morphological difference between fish from different origins by inferential statistics (McGarigal et al. 2000). The $p$-values are two-tailed unless otherwise stated. For interpreting the principal components in terms of the anatomical characters, we determined the component loadings, i.e. the principal component structure (see McGarigal et al. 2000). For assessing the significance of component loadings we followed Tabachnick and Fidell (2013). These authors recognise five levels of significance: loadings $>0.32$ or $<-0.32$ are poor, $>0.45$ or $<-0.45$ fair, $>0.55$ or $<-0.55$ good, $>0.63$ or $<-0.63$ very good, and $>0.71$ or $<-0.71$ excellent. These benchmarks account for $10 \%, 20 \%, 30 \%, 40 \%$ and $50 \%$ of the variance in the component, respectively. The software used was JMP 11 (SAS Institute).

\section{Genetic studies}

DNA was isolated from ethanol preserved tissues or scales using standard procedures as described earlier (Kramer et al. 2007).

Amplification of cytochrome $b$ by PCR and sequencing. The mitochondrial cytochrome $b$ gene was amplified by PCR and sequenced as in previous publications (Kramer et al. 2007). The aligned sequences were analysed by MEGA 6.04 (Tamura et al. 2013). Maximum likelihood was used to reconstruct the phylogeny. The conditions were as follows. As a substitution model we used the general time reversible

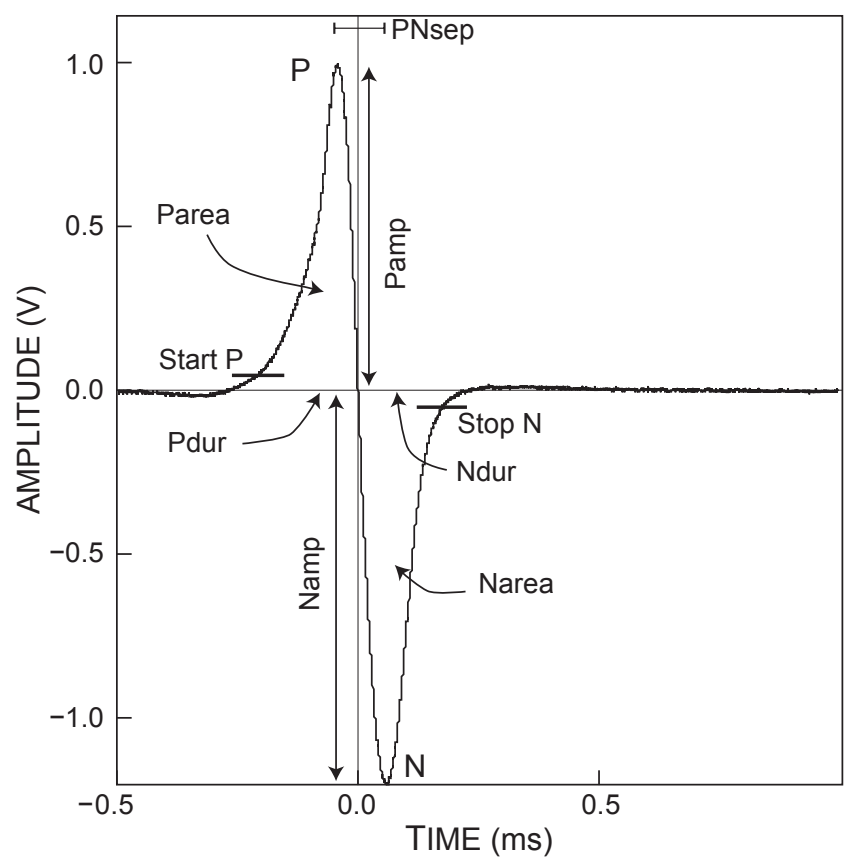

Figure 4: Electric organ discharge of a Marcusenius multisquamatus. The characters analysed and their definitions are indicated (modified from Kramer and Wink 2013)

model; rates among sites were gamma distributed with invariant sites $(\mathrm{G}+\mathrm{l})$ and five discrete gamma categories. As tree inference options the ML heuristic method and nearestneighbour-interchange (NNI) were used. All codons were included. Phylogeny test: bootstrap method with 1000 replications.

Sequence data of newly recorded taxa are deposited in GenBank under the accession numbers given in the appropriate sections and Figure 10. 


\section{Systematics}

Marcusenius altisambesi Kramer, Skelton, van der Bank \& Wink, 2007

(Figure 2A: d)

Gnathonemus macrolepidotus: Gilchrist and Thompson (1913), pp 330-331

Marcusenius altisambesi Kramer, Skelton, van der Bank \& Wink, 2007, pp 681-684

Holotype: SAIAB 79135. Type locality: Upper Zambezi River comprised between Lisikili and Kalimbeza (or Kalambesa), $17^{\circ} 33^{\prime} \mathrm{S}, 24^{\circ} 29^{\prime} \mathrm{E}$ to $17^{\circ} 32^{\prime} 27.3^{\prime \prime} \mathrm{S}, 24^{\circ} 31^{\prime} 26.2^{\prime \prime} \mathrm{E}$; 22-26 km straight-line downstream from Katima Mulilo.

Okavango sample examined (Botswana, locality 4; Figure 1). A total of $n=32$ specimens of $M$. altisambesi, i.e. SAIAB 79140 (9), ZSM 35079 (1), ZSM 35080 (3), ZSM 35081 (6), all from the Okavango River, Makwena Lodge, near the township of Etsha no. 6, $19^{\circ} 07^{\prime} 30^{\prime \prime} \mathrm{S}, 2^{\circ} 22^{\prime} \mathrm{E}$, coll. FH van der Bank, J Engelbrecht and B Kramer, 20-22 Jan. 2001; SAIAB 79143 (6), ZSM 35096 (5), from the Okavango River at the nearby Guma Lagoon, 1857'46.6" S, 22²2'25.3" E, coll. FH van der Bank and B Kramer, 10-12 Aug. 2004; SAIAB 79141 (1), ZSM 35095 (1), details as in preceding paragraph, except for locality at Makwena, $19^{\circ} 03^{\prime} 13.85^{\prime \prime} \mathrm{S}$, $22^{\circ} 22^{\prime} 42.6^{\prime \prime}$ E, 12 Aug. 2004.

Genetic samples. IPMB 40471, IPMB 44638-44642, Botswana: Okavango: Guma Lagoon, 1857'46.6" S, $22^{\circ} 22^{\prime 25.3 " ~ E, ~ c o l l . ~ F H ~ v a n ~ d e r ~ B a n k ~ a n d ~ B ~ K r a m e r, ~ 10-12 ~}$ Aug. 2004.

Marcusenius caudisquamatus Maake, Gon \& Swartz, 2014 Holotype SAIAB 88684, Mhlatuze River, corresponding COI sequence (GenBank number KJ174311), corresponding cyt $b$ sequence (GenBank number KJ174301).

Genetic samples. IPMB 9123 (GenBank number DQ863647), IPMB 9124 (GenBank number DQ863648), South Africa: KwaZulu-Natal: Mhlatuze River: where feeding into Goedertrouw Dam, 28²5'30" S, 31¹9'30" E, 12 Aug. 1999, coll. JS Engelbrecht and B Kramer.

\section{Marcusenius desertus sp. nov.}

(Figure 2A: a, b)

Marcusenius multisquamatus Kramer \& Wink, 2013

Type specimens. Holotype, ZSM 43802, field no. 1, close to Cunene River mouth, $17^{\circ} 15^{\prime} 29.3^{\prime \prime}$ S, $11^{\circ} 45^{\prime} 55.0^{\prime \prime}$ E, 10 Oct. 2012, water conductivity $98 \mu \mathrm{S} \mathrm{cm} \mathrm{cm}^{-1}$ and temperature $19.7^{\circ} \mathrm{C}$ at $20: 40$ hours, coll. S Voges, FH van der Bank, $B$ Kramer [locality \#1, where there is a reed bed, $1 \mathrm{~km}$ from coastline].

Paratypes. SAIAB 200648 (ex ZSM 43806), field nos 17, 19; MRAC B5-08-P-1-2 (ex ZSM 43806), field nos 16, 18; ZSM 43803, field nos 2, 3, 5, 6; ZSM 43804, field nos 7-9; ZSM 43805, field nos 10, 11; ZSM 43806, field nos 13-15, 20, 21; ZSM 43807, field nos 22-25, locality \#1 as above, 11-16 Oct. 2012, coll. as above; ZSM 43808, field nos 26-28, locality \#2, $3.2 \mathrm{~km}$ upstream from the reed bed, $17^{\circ} 16^{\prime} 22.1^{\prime \prime} \mathrm{S}, 11^{\circ} 47^{\prime} 20.2^{\prime \prime} \mathrm{E}, 17$ Oct. 2012 , water conductivity $80 \mu \mathrm{S} \mathrm{cm} \mathrm{cm}^{-1}$ and temperature $22.4^{\circ} \mathrm{C}$ at 07:30 hours, coll. as above [4.2 km from coastline]; ZSM 43809, field nos R1-R9, locality \#3 still $1.1 \mathrm{~km}$ further upstream among mid-river rocks, $17^{\circ} 16^{\prime} 14.9^{\prime \prime}$ S, $11^{\circ} 47^{\prime} 49.3^{\prime \prime}$ E, 22 Oct. 2013, coll. FH van der Bank [5.3 km from coastline].

Non-types, examined. ZSM 41761 (11), specimens R1R11, from the Cunene River mouth, 17 15'29.3" S, $11^{\circ} 45^{\prime} 55.0^{\prime \prime}$ E, 15 Dec. 2009, coll. FH van der Bank; ZSM 41762 (2), specimens 49 and 51, same place, 8 Nov. 2010, coll. S Voges; ZSM 41765, specimen C113, same place, 17 Jan 2011, coll. S Voges; ZSM 41763, specimen Ü7, same place, 13 Jul. 2011, coll. S Voges; ZSM 41764 (9), specimens A110-A118, same place, 22 Nov. 2011, coll. S Voges. These specimens were not studied for EOD. Non-types not examined: ZSM 43810, field no. 4; ZSM 43811, field no. 12.

Genetic samples. IPMB 57459, IPMB 57461-57464, IPMB 57466-57469, Namibia: Cunene River mouth, 17¹5'29.3" S, $11^{\circ} 45^{\prime} 55.0^{\prime \prime} \mathrm{E}$, coll. FH van der Bank, 15 Dec. 2009. These tissue samples were taken from ZSM 41761 (11).

Type locality. The lowest part of the Cunene River close to its mouth.

Diagnosis. Marcusenius desertus is characterised by a combination of the following: short snout length (LSo) $43.6 \%$ (40.8-45.8\%) of head length (HL), small eye diameter (OD) $15.8 \%(11.9-19.5 \%)$ of head length, nares separation (Na) 15.7 (12.7-17.6) times in head length, short preanal distance (PAL) $60.5 \%(59.2-62.7 \%)$ of standard length (SL), short head length (HL) $19 \%(17.6-20.8 \%)$ of SL, long anal fin length (LA) $25.3 \%(23.7-27.4 \%)$ of SL. Distinctive cytochrome $b$ gene (see Results: Genetic studies).

Description. Head with terminal mouth well in front of eye, mental lobe on lower jaw protruding beyond upper jaw. Head and body dorso-laterally compressed. Dorsal fin situated about two thirds of standard length from snout, obliquely orientated, anteriorly higher and posteriorly lower, distal margin slightly crescentic with anterior two or three rays longer than posterior rays, number of rays $21(n=1)$, $23(n=4), 24(n=7), 25(n=3)$; anal fin opposite dorsal fin with distinctly more anterior origin, obliquely orientated, anteriorly lower and posteriorly higher, anterior rays longer than posterior ones, especially in males where they also appear stronger and often darkened, distal margin crescentic (in males only posterior to rounded, elongated anterior part of fin), number of rays $26(n=1), 28(n=3)$, $29(n=7), 30(n=3), 32(n=1)$. Scales cycloid with reticulate striae, scales extending anteriorly to operculum and pectoral fins (beyond pelvics). Number of circumpeduncular scales, $11(n=1), 12(n=2), 13(n=5), 14(n=5), 15(n=$ 2). Caudal peduncle relatively deep, subcylindrical entire length, usually $39.3 \%$ (34.5-42.6\%) in its length (Appendix). Electric organ discharge biphasic with pre-potential so weak it is not always noticeable (refer to Figure 7a). Significant sex difference in EOD, with male EODs usually of longer duration (406 \pm SD $12.6 \mu \mathrm{s}, n=10$, vs $359 \pm$ SD $8.8 \mu \mathrm{s}$ 
in females, $n=7$ ) and weaker $\mathrm{N}$-phase amplitude re: P-phase amplitude than females $(-1.064 \pm 0.027 \mathrm{~V}, n=10$, vs $-1.195 \pm 0034 \mathrm{~V}, n=7$, in females). Males approaching sexual maturity develop a kink in the base of the anal fin (e.g. Figure 2A: a) which is absent in juveniles and females where the anal fin base is straight. Colour in life: brownish grey with many distinct dark-brown blotches, except on head and belly, sometimes purple hue depending on the angle of light incidence, pelvic fins light and transparent, pectorals darker.

Colour in preservation: brown (Figure 2B).

Ecology. The environment is a harsh sand-and-gravel desert bare of most vegetation (disregarding lichens, etc.), except in immediate proximity to river (but even there rather rare); this storm-swept, cool, dry area occurring in Namibia's Skeleton Coast National Park on the Atlantic Ocean. There are no human settlements, except for rare military or mining posts and the like, due to the harsh conditions, and there are no roads. Few reed beds and no trees are found, not even along the river banks. The river bed is sandy or rocky, occasionally with steep cliffs bordering the river. Few insects, only a few bird species, and a few occasional mammals such as oryx, springbok and brown hyena were encountered. Cormorants nesting inland were seen to fly out to the sea for feeding.

Distribution. At present only known from the mouth of the Cunene River.

Relationships. Closest relative is $M$. multisquamatus on the basis of molecular phylogeny, morphological and EOD similarity.

Etymology. The specific name desertus refers to the Skeleton Coast desert.

Remarks. Marcusenius desertus sp. nov. is distinguished from $M$. multisquamatus by a combination of its shorter snout length (LSo/HL: $0.436 \pm$ SD $0.004, n=15$ vs $0.479 \pm$ SD $0.004, n=15$, respectively ), smaller eye diameter (OD/ $\mathrm{HL}: 0.158 \pm 0.006$ vs $0.21 \pm 0.007$ ), and smaller nares separation (greater value for head length divided by nares separation, $\mathrm{HL} / \mathrm{Na}: 15.7 \pm 0.38$ vs $13.65 \pm 0.31)$. In addition, its preanal distance (PAL/SL: $0.605 \pm 0.003$ vs $0.615 \pm$ 0.002 ) as well as head length (HL/SL: $0.19 \pm 0.0025$ vs 0.2 $\pm 0.0017)$ are usually shorter, and anal fin length (LA/SL: $0.253 \pm 0.0024$ vs $0.243 \pm 0.0019$ ) longer than in M. multisquamatus. The EOD of Marcusenius desertus sp. nov. males is weaker in N-phase amplitude, NAMP, than that of M. multisquamatus males $(X+\mathrm{SE}=-1.064+0.027(n=10)$ vs $X+\mathrm{SE}=-1.21+0.031(n=4)$ re: $\mathrm{P}$-phase amplitude $=$ $1 \mathrm{~V}$ ). Marcusenius desertus sp. nov. is distinguished from $M$. altisambesi by significantly $(p<0.01)$ higher counts in the number of scales around the caudal peduncle (SPc), the no. of scales along the lateral line (SLS), and the no. of dorsal fin rays (Appendix). Marcusenius desertus sp. nov. also shows significantly $(p<0.01)$ higher scores in its distance between the origin of the dorsal fin and the end of the caudal peduncle ( $\mathrm{pD} / \mathrm{SL})$, length of anal fin (LA/
$\mathrm{SL})$, caudal peduncle depth (CPD/CPL), and head length divided by nares separation ( $\mathrm{HL} / \mathrm{Na})$, and significantly $(p<0.01)$ lower scores in its preanal distance $(\mathrm{PAL} / \mathrm{SL})$ and head length (HL/SL) than $M$. altisambesi (Appendix). Marcusenius desertus sp. nov. is significantly $(p<0.01)$ distinguished from $M$. krameri in 14 characters of the present study, most clearly by its lower number of scales around the caudal peduncle (SPc), and lower number of scales along the lateral line (SLS). Marcusenius desertus sp. nov. also shows lower scores for length of snout (LSo/ $\mathrm{HL}$ ) and eye diameter (OD/HL), but higher scores for body depth (BD/SL), than M. krameri (among others; Appendix). The cyt $b$ gene is distinctive for Marcusenius desertus sp. nov.

\section{Marcusenius devosi Kramer, Skelton, van der Bank \& Wink, 2007}

Holotype: SAIAB 79138

Genetic samples. IPMB 22668 (GenBank number DQ863666), IPMB 22669 (GenBank number DQ863667), Kenya: Tana River: Tana Primate Research Centre, $1^{\circ} 52^{\prime 38}$.1" S, 40²'22.5" E, 5 Sep. 2001, coll. L deVos and B Kramer.

\section{Marcusenius krameri Maake, Gon \& Swartz, 2014}

(Figure 2A: e)

Marcusenius Limpopo population: Kramer et al. (2007), p. 661

Holotype: SAIAB 188295, coll. P Maake and O Gon, 14 Oct 2010. Corresponding COI sequence (GenBank number KJ174307), corresponding cyt $b$ sequence (GenBank number KJ174297).

Type locality. Mogalakwena River (also known as the Nyl River), Modimolle town, Pretoria Street, above a drift, $24^{\circ} 42^{\prime} 04.2^{\prime \prime}$ S, $28^{\circ} 24^{\prime} 40.8^{\prime \prime}$ E, Limpopo River system, South Africa.

Limpopo System sample (South Africa, locality 5, Figure 1 ), examined. A total of $n=22$ specimens: SAIAB 88845 (15 specimens, field nos Mogol 01-Mogol 04, Mogol 15, Mogol 16, Mogol 25, Mogol 26, Mogol 29, Mogol 32-Mogol 34, Mogol 37, Mogol 38, Mogol 57), and ZSM 39535 (7) (specimen field nos Mogol 18, Mogol 19, Mogol 22-Mogol 24, Mogol 27, Mogol 36), all from South Africa: Limpopo System: Mokolo (Mogol) River: at road bridge, North of Hermanusdorings, $24^{\circ} 06^{\prime} 49.65^{\prime \prime} \mathrm{S}, 27^{\circ} 48^{\prime} 09.11^{\prime \prime} \mathrm{E}$, elevation 932 m, 20 Oct. 2008, coll. A Hoffman and B Kramer.

Genetic samples. SAIAB 191224 A150 and A251. Paragenetypes COI (GenBank numbers KJ174305 and KJ174306, respectively), Paragenetypes cyt $b$ (GenBank numbers KJ174295 and KJ174296, respectively). Limpopo River system, South Africa: Mogalakwena River (also known as the $\mathrm{Nyl}$ ), Modimolle town, $24^{\circ} 42^{\prime} 04.2^{\prime \prime} \mathrm{S}$, $28^{\circ} 24^{\prime} 40.8^{\prime \prime} \mathrm{E}$, coll. P Maake and O Gon, 14 Oct. 2010 (cited from Maake et al. 2014).

Marcusenius lucombesi Maake, Gon \& Swartz, 2014 Holotype: SAIAB 73884. Lucombe River, Lucombe stream 
pools, Nyati Road, Niassa Game Reserve, $12^{\circ} 5^{\prime} 15^{\prime \prime} \mathrm{S}$, 37³3'38" E, Ruvuma River system.

Genetic samples. SAIAB 73884 (GenBank number KJ174293), SAIAB 191226 (GenBank number KJ174294), Mozambique, Niassa Reserve: Ruvuma System, Lucombe Stream pools, Nyati Road, Niassa Game Reserve, $12^{\circ} 05^{\prime} 15^{\prime \prime} \mathrm{S}, 037^{\circ} 33^{\prime} 38^{\prime \prime}$ E, 22 Aug. 2003, coll. R Bills.

\section{Marcusenius macrolepidotus (Peters, 1852)}

Mormyrus macrolepidotus Peters, 1852, p. 275

Marcusenius macrolepidotus: Taverne (1971), p. 103;

Kramer et al. (2007), p. 677 (see full name history there)

Genetic sample. IPMB 22682 (GenBank number DQ863662), IPMB 22684 (GenBank number DQ863665), Mozambique: Buzi System: Lucite River: Nyangapwa

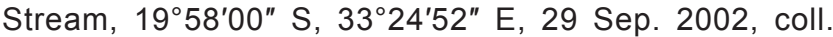
R Bills, S Chimela and A Chivindzi.

\section{Marcusenius multisquamatus Kramer \& Wink, 2013 (Figure 2A: c)}

Holotype: SAIAB 78781. Type locality: Namibia: Cunene River: Epupa Falls, Hot Springs campsite, estimated 300 $\mathrm{m}$ upstream from the Falls, $17^{\circ} 00^{\prime} 07^{\prime \prime} \mathrm{S}, 13^{\circ} 14^{\prime} 57^{\prime \prime} \mathrm{E}$, about $600 \mathrm{~m}$ elevation. Paratypes: SAIAB 78780 (2), SAIAB 78792; ZSM 38526 (2), ZSM 38527 (2), Namibia: Cunene River: Epupa Falls, Hot Springs campsite, examined (locality 1 in Figure 1), coll. E Swartz, B Kramer, and $L$ da Costa, from 11 Aug. 2006 to 17 Aug. 2006, and SAIAB 78785 (2), SAIAB 78789 (2), ZSM 38528, ZSM 38529 (2), Ruacana Falls, Hippo Pool campsite, just below the falls, $17^{\circ} 24^{\prime} 24^{\prime \prime} \mathrm{S}, 14^{\circ} 13^{\prime} 01^{\prime \prime} \mathrm{E}$, about 800 m elevation, coll. E Swartz and B Kramer, from 18 Aug. 2006 to 23 Aug. 2006.

Samples examined for genetics. IPMB 43971-43974, Namibia: Cunene River: Epupa Falls, $17^{\circ} 00^{\prime} 07^{\prime \prime} \mathrm{S}$, 13 $14^{\prime} 57^{\prime \prime}$ E, coll. E Swartz and B Kramer, 14 Aug. 2006; IPMB 43975-43978, as before, but 15 Aug. 2006; IPMB 43993, as before, but 17 Aug. 2006; IPMB 43980, Namibia: Cunene River: Ruacana Falls, $17^{\circ} 24^{\prime} 24^{\prime \prime} \mathrm{S}, 14^{\circ} 13^{\prime} 01^{\prime \prime} \mathrm{E}$, coll. E Swartz and B Kramer, 19 Aug. 2006; IPMB 43986, 43988, as before, but 21 Aug. 2006; IPMB 43990, as before, but 22 Aug. 2006; GenBank accession numbers: KC202227-KC202230; KC202238-KC202258.

\section{Marcusenius pongolensis (Fowler, 1934)}

Gnathonemus macrolepidotus: Gilchrist and Thompson (1913), pp 330-331

Gnathonemus pongolensis Fowler, 1934, p. 419, Figure 6

Gnathonemus macrolepidotus: Crass (1960), p. 416

Marcusenius pongolensis: Taverne (1971), p. 103; Kramer

et al. (2007), p. 684, Figures 1D, 1M

Holotype (unique): ANSP 54950.

Genetic sample. IPMB 44644, South Africa: Incomati System: near southern border of Kruger National Park, coll. $\mathrm{J}$ Engelbrecht and $\mathrm{FH}$ van der Bank.

\section{Results}

\section{Morphology}

The four geographic bulldog fish samples studied differed amongst each other significantly in morphology, as shown by the result of a multivariate analysis (MANOVA, $p<$ 0.0001 , Table 1.) Overall, there was at least one pair of samples per character that differed significantly in univariate ANOVAs $(p \leq 0.0075$, Table 1). Post hoc tests within each ANOVA showed which sample pairings differed for each character individually.

The two samples morphologically closest to each other were the two Cunene samples. The river mouth samples had a shorter snout length per head length (LSo/HL), a smaller eye diameter per head length $(\mathrm{OD} / \mathrm{HL})$, and a greater value for head length divided by nares separation $(\mathrm{HL} / \mathrm{Na})$ than the escarpment sample $(p<0.01)$. Also preanal distance (PAL/SL) and head length $(\mathrm{HL} / \mathrm{SL})$ were shorter, and anal fin length (LA/SL) longer, at $p<0.05$. The river mouth sample ( $n=7$ males, 8 females) and the escarpment sample ( $n=8$ males, 7 females) were of similar size (see Appendix).

The comparison of the two Cunene samples on one hand with their geographically closest neighbour, $M$. altisambesi from the Okavango on the other, confirmed the differentiation of both: for the escarpment sample by seven characters (six of which had already been identified by Kramer and Wink 2013), whereas the river mouth sample even differed by nine characters $(p<0.01$, plus two at $p<0.05)$. The two Cunene samples when compared to $M$. krameri differed in 16 and 14 (for the latter, plus one at $p<0.05$ ) characters for the escarpment and the river mouth samples, respectively, indicating very marked differentiation. The Okavango and Mokolo River samples were also well differentiated from each other by nine (plus one at $p<0.05$ ) characters (Table 1).

The present sample of bulldog fish from the Cunene River mouth (sampled at close to sea level) proved significantly differentiated from the $M$. multisquamatus sampled at the Cunene Escarpment (at 600-800 m elevation), also when using other multivariate procedures, confirming previous work (Kramer and Wink 2013). Principal component analysis on 19 morphological characters showed nonoverlapping distributions of individual points for the two Cunene River samples, compared to a sample of $M$. krameri from the Mokolo River, South Africa (Figure 5a, Table 1). In discriminant analysis the three samples showed non-overlapping 95\% confidence circles and distinct distributions of individual points with no misidentifications (Figure $5 b)$. In spite of only 15 characters being available in the comparison including the Okavango sample rather than the Mokolo sample, a discriminant analysis yielded similar results, again with zero misidentifications (Figure 6b). The PCA representation of the same data (Figure 6a) showed segregation of points according to groups, however, with some overlap by outliers, a consequence from the missing Okavango data for four characters, among them one of the principal ones, orbital diameter (OD).

A PCA was conducted including all four geographic samples. The PCA caught $73.7 \%$ of the variation of the dataset in the first three components, proving efficient 
reduction of redundancy (Table S2, available online). Principal component 1 seemed to represent a gradient mainly for the posterior part of the trunk and tail features, with scores for body depth (BD/SL), caudal peduncle depth (CPD/CPL), anal fin length (LA/SL; all 'excellent'), preanal length (PAL/SL) and dorsal fin length (LD/SL; both 'good') being high when those for the number of caudal peduncle scales (SPc, 'excellent'), the number of scales in lateral series (SLS, 'good') and caudal peduncle length (CPL/SL, 'good') were low, and vice versa. Principal component 1 was in addition loaded by certain head features, such as scores for head length divided by nares separation (HL/ $\mathrm{Na}$, 'excellent') being high when those for length of snout (LSo/HL and LSc/HL; 'excellent') and head length ( $\mathrm{HL} / \mathrm{SL}$; 'poor') were low, and vice versa. Principal component 2 was loaded by only three highly significant ('excellent') characters: scores for the distance from the dorsal fin origin to the end of the caudal peduncle ( $\mathrm{pD} / \mathrm{SL}$, 'excellent'), the length of the dorsal fin and its ray number (LD/SL and $\mathrm{nD}$, both 'fair'), the length of the anal fin (LA/SL, 'fair') and its ray number ( $\mathrm{nA}$, 'poor'), and the number of caudal peduncle scales (SPc, 'poor') were high when predorsal and preanal lengths (PDL/SL, PAL/SL, 'excellent') as well as head length (HL/SL, 'good') were low. Principal component 3 was loaded negatively by caudal peduncle length ('good') and several 'poor' characters, both positive and negative.

\section{Electric organ discharges}

The pulse waveforms of the EODs all showed a head-positive $\mathrm{P}$ phase that was followed by a head-negative $\mathrm{N}$ phase (Figure 7 ). Their duration and amplitude values re: $\mathrm{P}$ phase $=1$ volt (by definition) and a few more characters were studied for variation between the sexes and among the origins of the samples. As observed in all previous studies, the EOD characters studied did not differ between females and juveniles within a sample; therefore, they were combined and compared to males (Table 2). The sex of subadult males was recognised by the development of a kink of the anal fin base that precedes gonadal recrudescence, as reported in previous studies (Kramer 1997; Kramer et al. 2007).

The EOD waveforms of the Cunene River mouth sample $(n=17)$ differed clearly between the sexes. The EODs of females and juveniles showed stronger $\mathrm{N}$-phase amplitudes (Namp) and shorter duration values for the P-phase (Pdur), the $\mathrm{N}$ phase (Ndur), and the separation between $\mathrm{P}$-to- $\mathrm{N}$ phase peaks (PNsep; all $p<0.05$; Table 2) than the EODs of males. The Cunene Escarpment sample for female EODs $(n=3)$ was too small for ANOVA; however, a similar female-male difference was observed in P-phase (Pdur) and $\mathrm{N}$-phase duration (Ndur). The male EODs of the river mouth samples exhibited significantly weaker $\mathrm{N}$-phase values (Namp) than the escarpment samples: ANOVA $F_{1,12}=7.857, p=0.016$ (for mean values and standard errors, see Table 2).

The Okavango sample, M. altisambesi $(n=38)$, also differed among the sexes. Similar to the Cunene River mouth sample, N-phase amplitude (Namp) was stronger in the EODs of females and juveniles, and $\mathrm{N}$ phase duration (Ndur) and $\mathrm{P}-\mathrm{N}$ separation shorter than in males $(p \leq$ $0.0179)$. The greater area under the $N$ phase (Narea) in

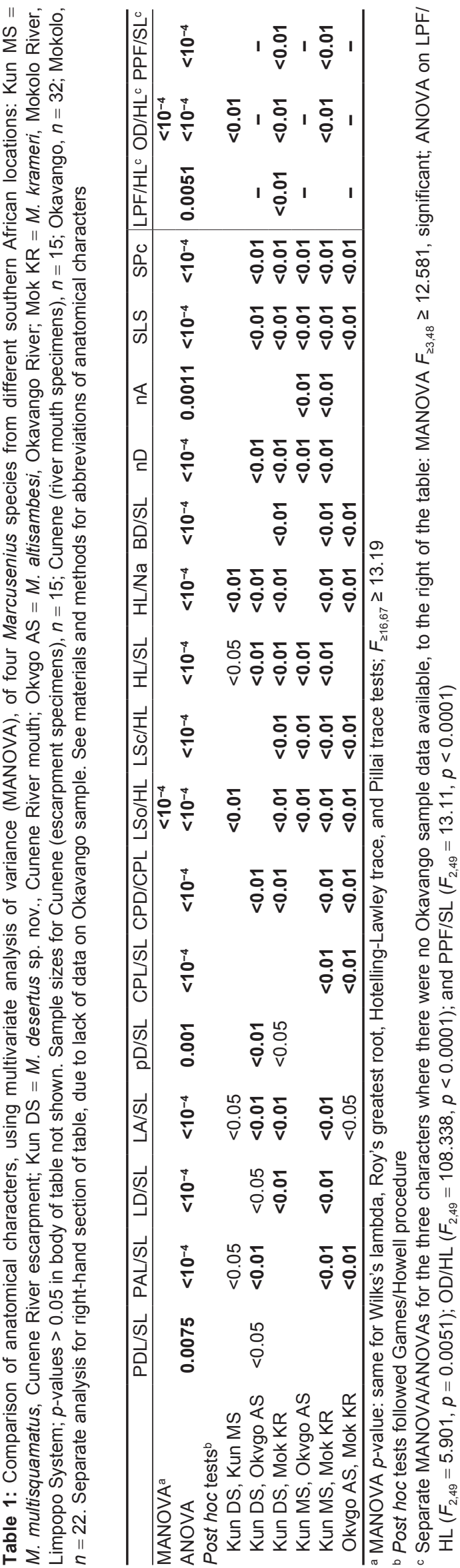




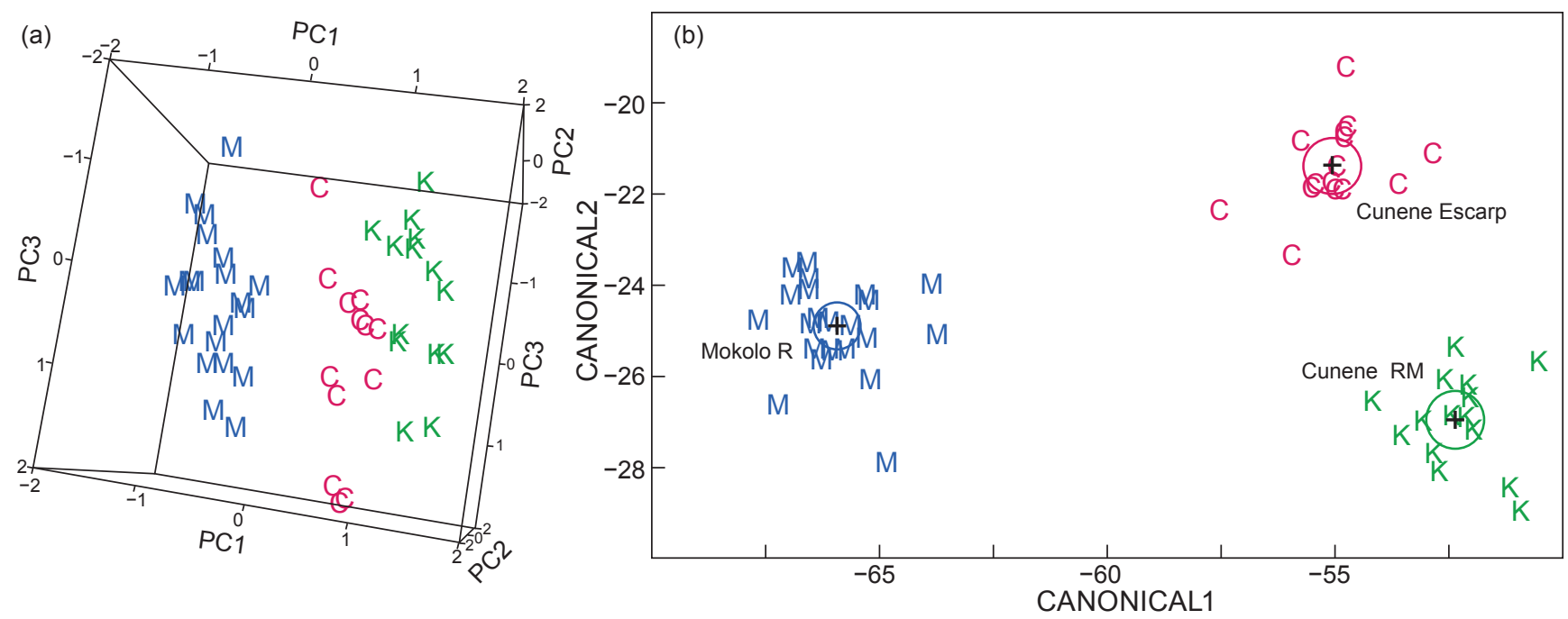

Figure 5: (a) Principal component analysis on morphology for three samples of bulldog fish. (b) Discriminant analysis on morphology for the same samples of bulldog fish. $\mathrm{C}=$ Marcusenius multisquamatus from the Cunene escarpment $(n=15) ; \mathrm{K}=$ Marcusenius multisquamatus from the Cunene River mouth $(n=15) ; \mathrm{M}=$ M. krameri from the Mokolo River, Limpopo System $(n=22)$. The 19 characters included were: $\mathrm{PDL} / \mathrm{SL}, \mathrm{PAL} / \mathrm{SL}, \mathrm{LD} / \mathrm{SL}, \mathrm{LA} / \mathrm{SL}, \mathrm{pD} / \mathrm{SL}, \mathrm{CPL} / \mathrm{SL}, \mathrm{CPD} / \mathrm{CPL}$, LSo/HL, LSc/HL, HL/SL, HL/Na, BD/SL, nD, nA, SPc, SLS, LPF/HL, OD/HL and $\mathrm{PPF} / \mathrm{SL}$

(a)

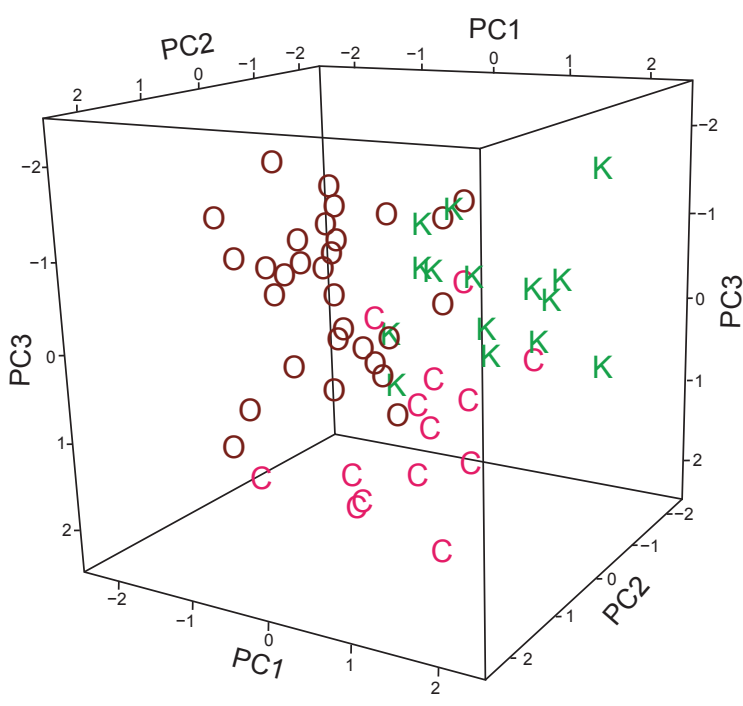

(b)

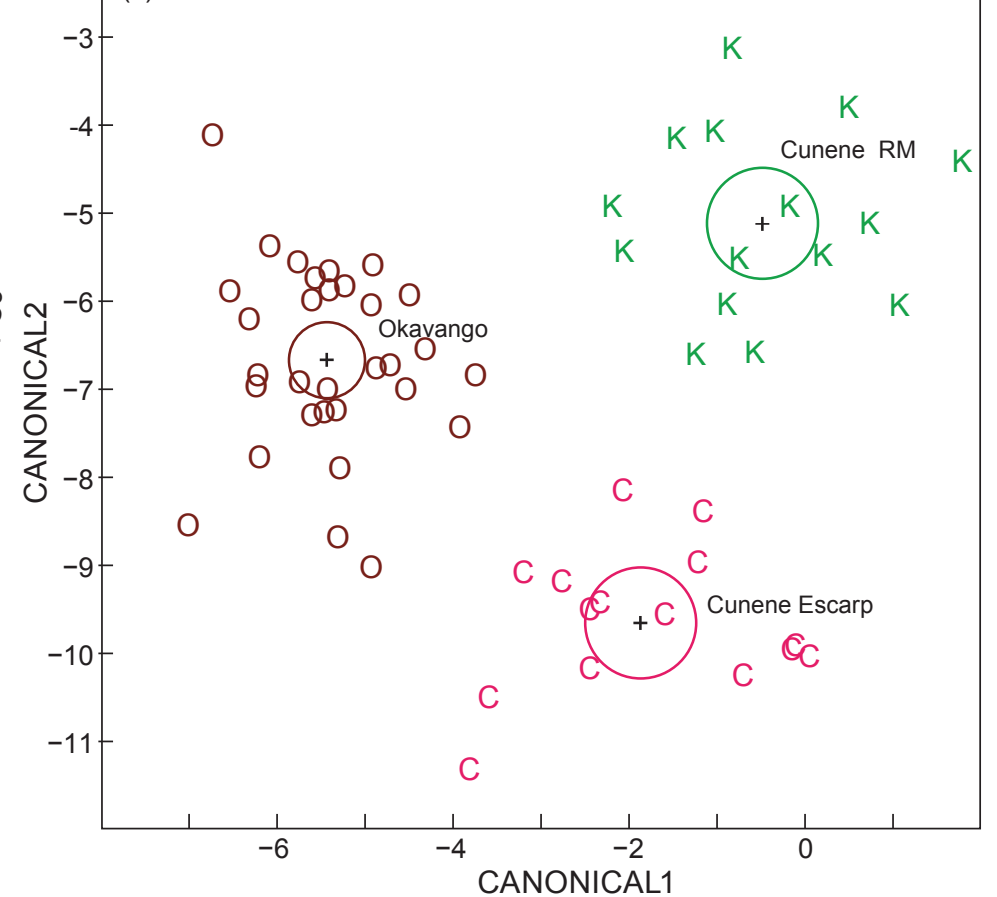

Figure 6: (a) Principal component analysis on morphology for three samples of bulldog fish. (b) Discriminant analysis on morphology for the same samples of bulldog fish. $\mathrm{C}=$ Marcusenius multisquamatus, Cunene escarpment $(n=15) ; \mathrm{K}=$ Marcusenius multisquamatus, Cunene River mouth $(n=15) ; \mathrm{O}=\mathrm{M}$. altisambesi, Okavango River $(n=32)$. The 15 characters included were: PDL/SL, PAL/SL, LD/SL, LA/SL, CPL/ $\mathrm{SL}, \mathrm{CPD} / \mathrm{CPL}$, LSo/HL, LSc/HL, HL/SL, HL/Na, BD/SL, nD, nA, SPc and SLS

male than female EODs only narrowly missed significance $(p=0.052)$.

No sex difference was found in the Mokolo River sample (M. krameri). This lack of a difference is probably due to the smaller body size (SL) of specimens compared to the other samples of the present study. Other South African Marcusenius samples of a more mature size do show an EOD sex difference (Kramer 1997; Kramer et al. 2007). 


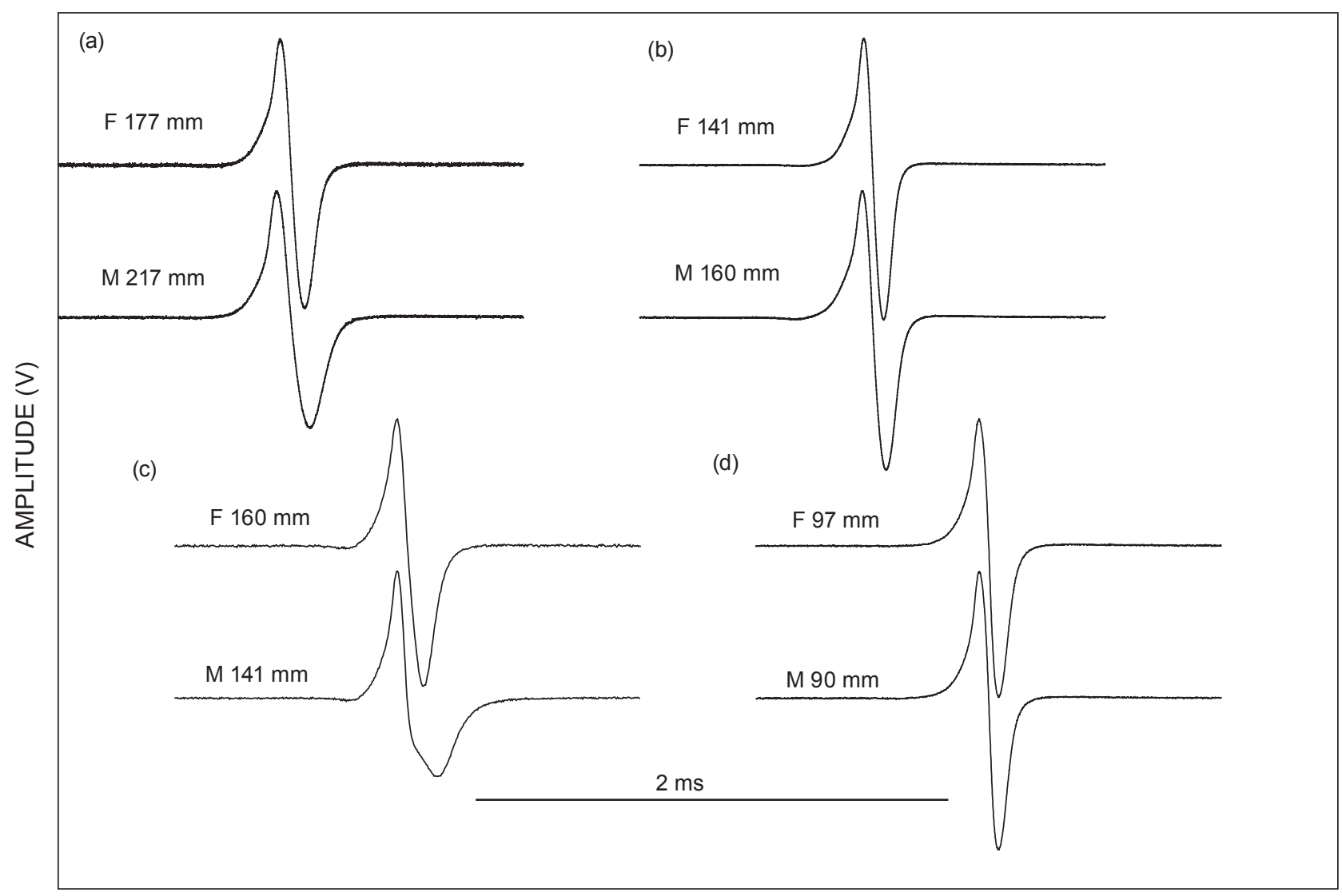

TIME (ms)

Figure 7: Representative electric organ discharge (EOD) waveforms of the four bulldog fish samples studied. $F$ refers to recordings from females, given with standard length SL; M, same for males. (a) EODs recorded from specimens sampled at the Cunene River mouth; (b) Cunene Escarpment at Epupa Falls; (c) Makwena, Okavango Delta; (d) Mokolo River, Limpopo System. Oscilloscope traces are normalised to the same positive peak amplitude (Pamp) of +1 volt from baseline, and shown at the same sweep speed (see time bar)

Discriminant analysis for female and juvenile EODs showed significant differentiation by non-overlapping $95 \%$ confidence circles for the Mokolo, Okavango and Cunene River mouth samples (the Cunene escarpment sample only had three females and was excluded from the analysis; Figure $8 b)$. Five $(9.6 \%)$ of the 52 specimens were misclassified: two river mouth specimens as Okavango specimens, and three Okavango specimens as river mouth specimens. In the PCA representation, segregation of points was clearly present but incomplete (Figure 8a).

Male samples were clearly differentiated for Mokolo, Okavango and Cunene River mouth samples (Figure 9a, $9 b$ ). The Cunene Escarpment sample only had four males and was excluded from the analysis. With none of the specimens misclassified, discrimination was even better than with the females plus juveniles sample, and PCA analysis only showed a single overlapping point.

\section{Genetic studies}

The phylogenetic reconstruction from nucleotide sequences of mitochondrial cytochrome $b$ with maximum likelihood shows that $M$. altisambesi, $M$. multisquamatus and $M$. desertus sp. nov. form a monophyletic species complex (bootstrap support 97\%; Figure 10). Table 3 documents that $M$. multisquamatus and $M$. desertus sp. nov. differ from $M$. altisambesi by two common nucleotide substitutions (GT in positions 643 and 669 instead of $\mathrm{AC}$ in M. altisambesi, which clusters basal in this species complex). Marcusenius multisquamatus and $M$. desertus $\mathrm{sp}$. nov. are sister taxa and closely related. All specimens of $M$. multisquamatus share a nucleotide substitution in position 813; i.e. they carry an A instead of $\mathrm{G}$ in $M$. altisambesi and $M$. desertus sp. nov. Six specimens of $M$. multisquamatus have an additional variable site at position 120 ( $T$ instead of $C$ ) and in consequence form a monophyletic group. The bootstrap values are only $45 \%$ for the $M$. multisquamatus and $M$. desertus sp. nov. node, but the consistent nucleotide substitution makes this separation reliable.

Marcusenius multisquamatus is separated from $M$. desertus sp. nov. by a mean genetic distance of $0.2 \%$ (p-distance) and both from $M$. altisambesi by distances of up to $0.6 \%$ and $0.4 \%$, respectively. These distances provide an estimated time scale for divergence of 1.01-0.67 million years for the separation of $M$. multisquamatus and $M$. desertus sp. nov. from $M$. altisambesi. The divergence of $M$. multisquamatus from $M$. desertus $\mathrm{sp}$. nov. took place maximally 340000 years ago assuming a molecular clock 
Table 2: Electric organ discharge (EOD) waveform characters in females and juveniles combined $(\phi+q)$, compared to males $\left(\hat{\jmath} \delta^{\lambda}\right)$ of three Marcusenius species for samples from different southern African locations. Cunene MS = M. multisquamatus from Cunene escarpment; Cunene DS = M. desertus sp. nov., Cunene River mouth; Okvgo AS = M. altisambesi, Okavango River; Mokolo KR = M. krameri, Mokolo River. For abbreviations of EOD waveform characters, see Materials and methods

\begin{tabular}{|c|c|c|c|c|c|c|c|}
\hline Statistic & $\begin{array}{l}\text { Namp } \\
(\mathrm{V})\end{array}$ & $\begin{array}{l}\text { Pdur } \\
(\mu \mathrm{s})\end{array}$ & $\begin{array}{c}\text { Ndur } \\
(\mu \mathrm{s})\end{array}$ & $\begin{array}{c}\text { PNsep } \\
(\mu \mathrm{s})\end{array}$ & $\begin{array}{c}\text { Parea } \\
(\mathrm{V} \times \mu \mathrm{s})\end{array}$ & $\begin{array}{c}\text { Narea } \\
(\mathrm{V} \times \mu \mathrm{s})\end{array}$ & $\begin{array}{c}\mathrm{SL} \\
(\mathrm{cm})\end{array}$ \\
\hline \multicolumn{8}{|l|}{ Mokolo KR $(n=22)$} \\
\hline o+ Mean/median* (17) & -1.292 & 197.65 & 149.49 & 75.86 & 79.11 & 92.87 & $8.2^{*}$ \\
\hline SE/SIQ* & 0.021 & 3.66 & 3.94 & 1.78 & 1.61 & 2.17 & $0.65^{*}$ \\
\hline ANOVA $p$ & $>0.2$ & $>0.2$ & $>0.2$ & $>0.2$ & $>0.2$ & $>0.2$ & $6.8-9.7^{1}$ \\
\hline đōMean/median* (5) & -1.238 & 193.46 & 149.1 & 76.22 & 76.94 & 88.68 & $9^{*}$ \\
\hline SE/SIQ* & 0.018 & 3.52 & 3.24 & 2.03 & 1.51 & 2.04 & $\begin{array}{c}0.4^{*} \\
8.1-9.2^{1}\end{array}$ \\
\hline \multicolumn{8}{|l|}{ Okavango AS $(n=38)$} \\
\hline o+ $q$ Mean/median* (28) & -1.192 & 184.1 & 165.9 & 90 & 81.4 & 99.1 & $10^{*}$ \\
\hline $\mathrm{SE} / \mathrm{SIQ}^{*}$ & 0.018 & 1.73 & 5.62 & 2.97 & 0.91 & 2.23 & $0.57^{*}$ \\
\hline ANOVA $p$ & 0.0179 & $>0.3$ & 0.0024 & 0.0107 & $>0.3$ & 0.052 & $7.1-16.9^{1}$ \\
\hline${ }^{\top}$ Mean/median* (10) & -1.068 & 187.61 & 216.16 & 111.9 & 83.5 & 109.8 & $14.5^{*}$ \\
\hline $\mathrm{SE} / \mathrm{SIQ}$ & 0.069 & 4.08 & 20.75 & 11 & 2.75 & 6.45 & $\begin{array}{c}1.2^{*} \\
13.5-18.1\end{array}$ \\
\hline \multicolumn{8}{|c|}{ Cunene MS (escarpment, $n=7$ ) } \\
\hline 우 Mean/median* (3) & -1.166 & 192.3 & 176.9 & 100.3 & 82.9 & 106.2 & $14.1^{*}$ \\
\hline SE/SIQ* & 0.031 & 11.12 & 32.2 & 12.56 & 6.67 & 14.88 & $0.49^{*}$ \\
\hline ANOVA $p$ & - & - & - & - & - & - & $13.6-14.9^{1}$ \\
\hline ởMean/median* (4) & -1.21 & 209.75 & 196.75 & 99.9 & 91.67 & 117.15 & $15.8^{*}$ \\
\hline $\mathrm{SE} / \mathrm{SIQ}^{*}$ & 0.031 & 12.97 & 32.22 & 7.95 & 7.49 & 14.65 & $\begin{array}{c}1.5^{*} \\
15.4-20.9\end{array}$ \\
\hline \multicolumn{8}{|c|}{ Cunene DS (river mouth, $n=17$ ) } \\
\hline 우Mean/Median* (7) & -1.195 & 198.33 & 160.94 & 89.44 & 84.19 & 99.04 & $13.2^{*}$ \\
\hline SE/SIQ* & 0.034 & 3.9 & 6.41 & 4.21 & 2.66 & 4.86 & $1.26^{*}$ \\
\hline ANOVA $p$ & 0.0121 & 0.0472 & 0.0136 & 0.0046 & $>0.1$ & $>0.2$ & $11.7-17.7^{1}$ \\
\hline 万ै Mean/median* (10) & -1.064 & 210.75 & 195.17 & 119.03 & 89.15 & 106.02 & $20.9^{*}$ \\
\hline SE/SIQ* & 0.027 & 3.94 & 9.15 & 6.79 & 1.89 & 4.86 & $\begin{array}{c}1.26^{*} \\
12.7-23.2\end{array}$ \\
\hline
\end{tabular}

${ }^{*}$ Median and SIQ (semi-interquartile range) for SL (standard length) only

${ }^{1} \mathrm{SL}$ also given as size range
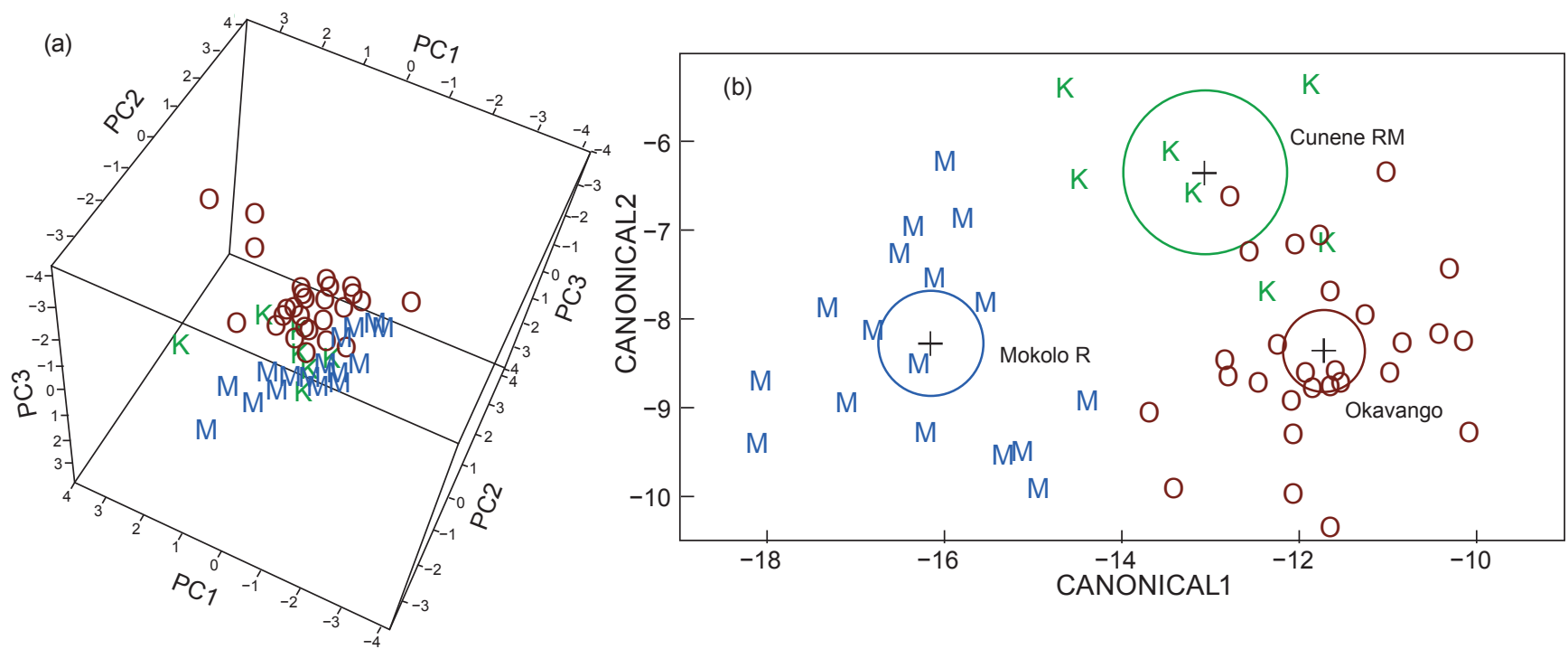

Figure 8: (a) Principal component analysis on electric organ discharges (EODs) for three samples of bulldog fish. (b) Discriminant analysis on electric organ discharges for the same samples of bulldog fish from various localities, females and juveniles (males excluded). $\mathrm{K}=$ specimens from the Cunene River mouth $(n=7)$; O = Okavango $(n=28) ; \mathrm{M}=$ Mokolo River $(n=17)$. Electric organ discharge characters included: Namp (V), Pdur ( $\mu \mathrm{s})$, Ndur $(\mu \mathrm{s})$, PNsep $(\mu \mathrm{s})$, Parea $(\mathrm{V} \times \mu \mathrm{s})$ and Narea $(\mathrm{V} \times \mu \mathrm{s})$ 

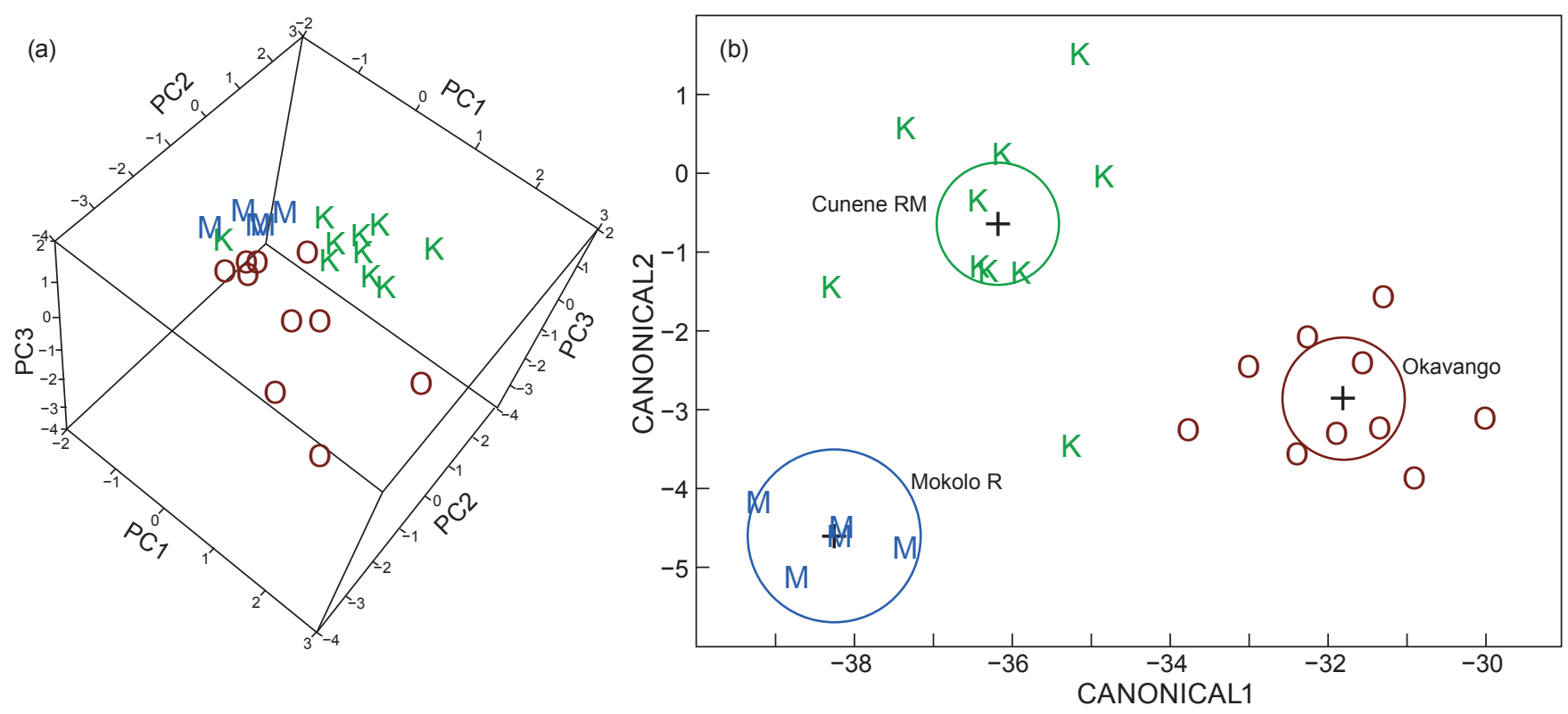

Figure 9: (a) Principal component analysis on electric organ discharges (EODs) for three samples of bulldog fish. (b) Discriminant analysis on electric organ discharges (EOD) for the same samples of male bulldog fish from various localities. $\mathrm{K}=$ specimens from Cunene River mouth $(n=10)$; O = Okavango $(n=10) ; \mathrm{M}=$ Mokolo River $(n=5)$. Electric organ discharge characters included: Namp (V), Pdur $(\mu \mathrm{s})$, Ndur $(\mu \mathrm{s})$, PNsep $(\mu \mathrm{s})$, Parea $(\mathrm{V} \times \mu \mathrm{s})$ and Narea $(\mathrm{V} \times \mu \mathrm{s})$

of $0.58 \%$ distance equals 1 million years (obtained for freshwater fish; Burridge et al. 2008).

The tree reconstruction also confirms the clades containing $M$. lucombesi, $M$. caudisquamatus and $M$. krameri and a second clade with $M$. pongolensis and $M$. macrolepidotus, as established by Maake et al. (2014). Van der Bank et al. (2012) also obtained similar differentiation for another freshwater fish species.

\section{Discussion}

We designate a new species for the Cunene River mouth, Marcusenius desertus sp. nov., because Cunene River mouth bulldogs are morphologically, genetically and electrophysiologically differentiated from Cunene Escarpment bulldogs. The re-examination of morphology revealed an even stronger differentiation than already observed in the preceding study by Kramer and Wink (2013) that was using alcohol-fixed river mouth specimens. In the present study three additional characters were included. Differentiation is supported by PCA, discriminant analysis (Figures 5 and 6 ) and the MANOVA/ANOVAs of Table 1. Table 1 also includes the comparison of the two Cunene samples to their 'next neighbour' sample, the one from the Okavango, and to a more distant relative sample from the Limpopo System, respectively. Cunene Escarpment and River mouth samples differed from each other in six morphological characters, and River mouth samples from the other two samples (Okavango and Mokolo) in 11 and 15 characters, respectively. Even although the genetic differences as revealed by cytochrome $b$ analysis were quite small, they indicate reproductive isolation and recent speciation. Alone, they would not be totally convincing to recognise $M$. desertus sp. nov. as a distinct species. Considering the morphological and electrophysiological data, the sequence data support the suggestion that $M$. desertus sp. nov. represents a unique lineage. In accordance with the phylogenetic species concept we therefore consider $M$. desertus sp. nov. as a valid species.

The recent addition of three new species by Maake et al. (2014) brought the number of southern African Marcusenius species, originally all thought to represent $M$. macrolepidotus Peters, 1852 (e.g. Skelton 2001), to nine; ten with $M$. desertus sp. nov. The southern African Marcusenius species are divided into two lineages, one that includes $M$. macrolepidotus and $M$. pongolensis, and another one that includes M. altisambesi and M. krameri (Maake et al. 2014), confirmed by the present study (Figure 10 and Table 3). Marcusenius multisquamatus and the Cunene River mouth sample ( $M$. desertus sp. nov.) form part of the altisambesi group (Kramer and Wink 2013), as does M. krameri (Maake et al. 2014), in spite of the great geographic distance.

Marcusenius species, as far as they have been studied, appear to be only weakly differentiated in EOD waveform in the whole of Africa. Examples illustrating this point are $M$. ussheri Günther, 1867 and M. senegalensis (Steindachner, 1870) in Côte d'Ivoire (Kramer 2013a), and M. devosi Kramer et al., 2007 in Kenya, the EODs of which are comparable to those of the southern African M. macrolepidotus and its nine former unrecognised species, eight of which have been studied for EOD. However, there is withingenus differentiation regarding to whether or not, or to what extent, male EOD pulses increase seasonally in duration which is linked to reproduction; e.g. $M$. altisambesi and $M$. ussheri (Kramer 1997, 2013a). This is in stark contrast to other mormyrid genera like Hippopotamyrus, Pollimyrus, Mormyrops and Mormyrus, where striking within-genus 


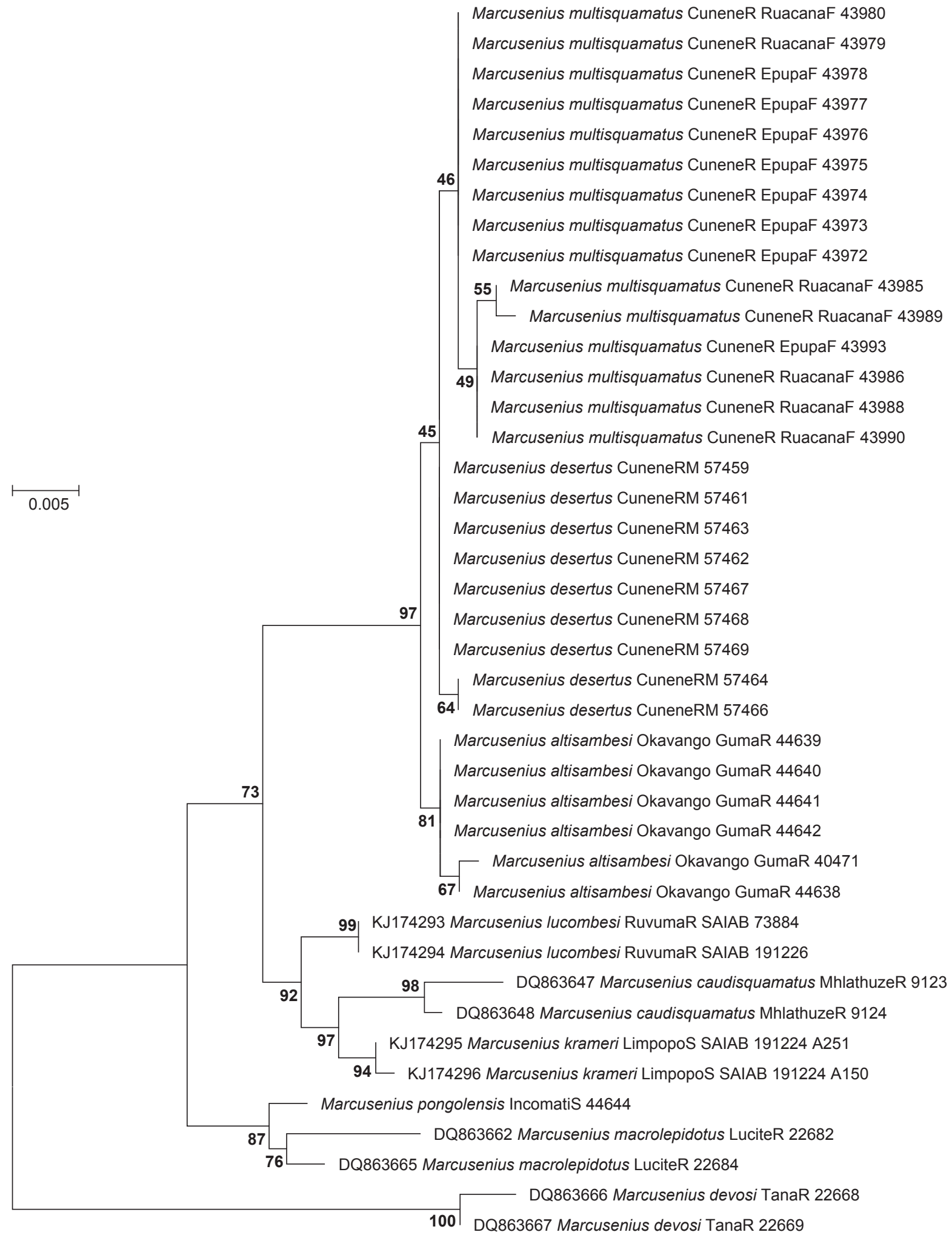

Figure 10: Molecular phylogeny of Marcusenius species from Cunene River and some of their relatives, based on cytochrome $b$ sequences from the present study and from GenBank (M. krameri, M. caudisquamatus, M. lucombesi by Maake et al. 2014). Phylogeny reconstruction by maximum likelihood illustrated as a phylogram in which branch length is correlated with genetic distance. Bootstrap values based on 1000 replicates indicated at the nodes. Locality names, SAIAB and IPMB accession numbers indicated for each sample separately; GenBank numbers where applicable. Cunene RM = Cunene River mouth, CuneneR EpupaF = just above Epupa Falls, CuneneR RuacanaF = just below Ruacana Falls (all Namibia); Okavango GumaL = Okavango River at Guma Lagoon, Botswana; RuvumaR = Ruvuma River, LuciteR = Lucite River, Buzi System (both Mozambique); MhlatuzeR = Mhlatuze River, LimpopoS = Limpopo System, IncomatiS = Incomati System (all South Africa); TanaR = Tana River (Kenya) 
Table 3: Variable sites in the cyt $b$ dataset for $M$. altisambesi, $M$. multisquamatus and $M$. desertus sp. nov. Informative nucleotide substitutions in bold type. Dot indicates an identical nucleotide to that shown in the first line. Locations of samples and IPMB nos given individually. GumaL = Guma Lagoon, Okavango; CuneneRM = Cunene River mouth; CuneneR_EpupaF = Cunene River, Epupa Falls; CuneneR_RuacanaF = Cunene River, Ruacana Falls; all from Namibia, except Guma Lagoon, Botswana

\begin{tabular}{c}
\hline Position \\
\hline 13356668 \\
23552461 \\
03255393
\end{tabular}

\#Marcusenius_altisambesi_Okavango_GumaL 44639 \#Marcusenius_altisambesi_Okavango_GumaL_44640 \#Marcusenius_altisambesi_Okavango_GumaL_44641 \#Marcusenius_altisambesi_Okavango_GumaL_44642 \#Marcusenius_altisambesi_Okavango_GumaL_40471 \#Marcusenius_altisambesi_Okavango_GumaL_44638 \#Marcusenius_desertus_CuneneRM_57459 \#Marcusenius_desertus_CuneneRM_57461 \#Marcusenius_desertus_CuneneRM_57463 \#Marcusenius desertus_CuneneRM 57462 \#Marcusenius_desertus_CuneneRM_57464 \#Marcusenius_desertus_CuneneRM_57466 \#Marcusenius_desertus_CuneneRM_57467 \#Marcusenius_desertus_CuneneRM_57468 \#Marcusenius_desertus_CuneneRM_57469 \#Marcusenius_multisquamatus_CuneneR_EpupaF_43972 \#Marcusenius_multisquamatus_CuneneR_EpupaF_43973 \#Marcusenius_multisquamatus_CuneneR_EpupaF_43974 \#Marcusenius_multisquamatus_CuneneR_EpupaF_43975 \#Marcusenius_multisquamatus_CuneneR_EpupaF_43976 \#Marcusenius multisquamatus CuneneR EpupaF 43977 \#Marcusenius_multisquamatus_CuneneR_EpupaF_43978 \#Marcusenius_multisquamatus_CuneneR_RuacanaF_43980 \#Marcusenius_multisquamatus_CuneneR_RuacanaF_43979 \#Marcusenius_multisquamatus_CuneneR_EpupaF_43993 \#Marcusenius_multisquamatus_CuneneR_RuacanaF_43986 \#Marcusenius_multisquamatus_CuneneR_RuacanaF_43988 \#Marcusenius_multisquamatus_CuneneR_RuacanaF_43990 \#Marcusenius_multisquamatus_CuneneR_RuacanaF_43989 \#Marcusenius_multisquamatus_CuneneR_RuacanaF_43985 differentiation of EODs among closely related species has been observed (Kramer et al. 2003; Kramer et al. 2004; Kramer and Swartz 2010; Kramer 2013b, 2013c; Kramer et al. 2014).

In spite of this weak effect of species on EOD waveform in Marcusenius, the two Cunene male EOD samples proved significantly different from each other in a comparison of $\mathrm{N}$-phase amplitude. The EODs of Cunene River mouth samples were well differentiated from the other two samples (Figure 9). The female EOD sample from the escarpment was too small to be included in inferential statistics procedures, but the other three female EOD samples (from the Okavango, Mokolo and the Cunene River mouth) were significantly differentiated from each other, as shown by discriminant analysis (Figure 8b).

Morphological differentiation between the Cunene River escarpment species $M$. multisquamatus and the river mouth species $M$. desertus sp. nov. seems to be due to several factors, one of them their genetic quasi-isolation over some considerable time (up to 340000 years; Table 3). Another factor is differences in ecology. We caught an originally marine invader, the nocturnal freshwater long-arm prawn, Macrobrachium vollenhoveni (Herklots, 1857), from reed beds at the Cunene River mouth (as also noted by de Moor et al. 2000), where bulldogs were hiding during the day. Macrobrachium vollenhoveni had previously been recorded in a 'pool near mouth in Cunene River', but also at Rocky Point and Möwe Point on the coastline of the Skeleton Coast National Park, $250 \mathrm{~km}$ south of the Cunene River mouth (Kensley 1970). The long-arm prawn also occurs on the Cape Verde islands, in Liberia, Angola (Kensley 1970), and 'commonly in the West African region' where its larval stages require brackish water conditions (Lawal-Are and Owolabi 2012).

The long-arm prawns with their reflective eyes (i.e. good night vision) and strong claws commonly attacked fish struggling in a net when incapable of escape, resulting in severe damage to the fish when not recovered immediately after dark. Competition for food and hiding places between Macrobrachium prawns and fish was also observed in an on-site aquarium. The farthest upstream record of Macrobrachium vollenhoveni in the Albany Museum, Grahamstown, was $60 \mathrm{~km}$ from the Cunene River mouth at an elevation of $180 \mathrm{~m}$ (accession no. KUN123A). This is in contrast to the freshwater crab Potamonautes bayonianus (Brito-Capello, 1864) that occurred in riffles and rapids much higher up in the catchment (above Epupa Falls, at around 700 m elevation; de Moor et al. 2000). Potamonautes was not caught in the present study (river mouth).

At the river mouth, aerial insects like mayflies and caddisflies have not been seen, and were also missing in the survey by de Moor et al. (2000) from this location. Our searchlights for crocodiles were reflected from the wings of aerial insects floating in huge numbers on the water surface at Epupa and Ruacana Falls at night, and 24 mayfly species, 20 caddisfly species and 41 chironomid species were recorded by de Moor et al. (2000) above Epupa Falls. A nocturnal group feeding behaviour termed 'surface floating' was described in Marcusenius senegalensis (Steindachner, 1870) by Scheffel and Kramer (1997), and similar behaviour observed in several southern African bulldog species in an aquarium. At Epupa and Ruacana Falls, Kramer and Swartz (2010) caught three other mormyrid species in addition to bulldogs, Petrocephalus magnoculis, Hippopotamyrus longilateralis and Mormyrus lacerda, at the river mouth only one, Mormyrus lacerda. At Epupa or Ruacana Falls, no cormorants were seen, whereas they were abundant at the river mouth.

These observations show the great adaptability of the genus Marcusenius, member of a fully tropical freshwater family, to almost any kind of African habitat, provided there is some water. Marcusenius species occur in the northern sub-Saharan Sahel zone, with hot and dry summer conditions, where seasonally intermittent rivers dry up to a series of sparse pools only $10 \%$ their normal length, which dry up completely in the lower reaches (Mali: Paugy 2002; Burkina Faso/Côte d'Ivoire: Kramer 2013a). Marcusenius species also occur at temperatures so low 
central or northern African species would not survive in certain southern African habitats, such as the escarpment of KwaZulu-Natal in South Africa or the Kwando River in the Caprivi Strip area, Namibia, in winter.

Acknowledgments - We wish to thank the following persons and institutions: the Namibian government for permission to visit the Cunene River mouth, Skeleton Coast National Park. We thank Mr. Stephanus Voges, Ministry of Fisheries and Marine Resources, who helped in many ways, including the catching of fish. We thank the Northern Namibia Development Company, in particular the Managing Director Mr Johan van Rooyen, who graciously hosted us at their camp. We thank $\mathrm{P}$ Maake and $\mathrm{O}$ Gon for help with identifying the Mokolo River sample, and R Greenfield for help in the field in many ways. We thank R Bills (SAIAB), $H$ James and D Weeks, Albany Museum, Grahamstown, South Africa, for help with collection records and decapod identification. We also thank Birgit Blaul, Lena Dietz, Ellen Fröhlich, Silvia Förster, Susanne Füssel and Kathrin Kahler, Regensburg University morphology team, for measuring assistance, Ellen Fröhlich for graphical assistance, and the Deutsche Forschungsgemeinschaft (DFG) (grant no. KR 446/12-2) and National Research Foundation, South Africa, for funding assistance.

\section{References}

Agnèse J-F, Bigorne R. 1992. Premières données sur les relations génétiques entre onze espèces ouest-Africaines de Mormyridae (Teleostei, Osteichthyes). Revue d'Hydrobiologie Tropicale 25: 253-261.

Arnegard ME, Hopkins CD. 2003. Electric signal variation among seven blunt-snouted Brienomyrus species (Teleostei: Mormyridae) from a riverine species flock in Gabon, Central Africa. Environmental Biology of Fishes 67: 321-339.

Arnegard ME, Jackson BS, Hopkins CD. 2006. Time-domain signal divergence and discrimination without receptor modification in sympatric morphs of electric fishes. Journal of Experimental Biology 209: 2182-2198.

Arnegard ME, McIntyre PB, Harmon LJ, Zelditch ML, Crampton WGR, Davis JK et al. 2010. Sexual signal evolution outpaces ecological divergence during electric fish species radiation. American Naturalist 176: 335-356.

Bell-Cross G, Minshull JL. 1988. The fishes of Zimbabwe. Harare: National Museums and Monuments of Zimbabwe.

Bullock TH, Heiligenberg W (eds). 1986. Electroreception. New York: John Wiley.

Bullock TH, Hopkins CD, Popper AN, Fay RR (eds). 2005. Electroreception. New York: Springer.

Burridge CP, Craw D, Fletcher D, Waters JM. 2008. Geological dates and molecular rates: fish DNA sheds light on time dependency. Molecular Biology and Evolution 25: 624-633.

Crass RS. 1960. Notes on the freshwater fishes of Natal with descriptions of four new species. Annals of the Natal Museum 14: 405-458.

Crawford JD, Hopkins CD. 1989. Detection of a previously unrecognized mormyrid fish (Mormyrus subundulatus) by electric discharge characters. Cybium 13: 319-326.

de Moor FC, Barber-James HM, Harrison AD, Lugo-Ortiz CR. 2000. The macroinvertebrates of the Cunene River from the Ruacana Falls to the river mouth, and assessment of the conservation status of the river. African Journal of Aquatic Science 25: 105-122.

Eschmeyer WN, Fricke R, van der Laan R (eds). n.d. Catalog of fishes: genera, species, references. Available at http:// researcharchive.calacademy.org/research/ichthyology/catalog/ fishcatmain.asp [accessed 12 February 2016].

Feulner PGD, Kirschbaum F, Mamonekene V, Ketmaier V,
Tiedemann R. 2007. Adaptive radiation in African weakly electric fish (Teleostei: Mormyridae: Campylomormyrus): a combined molecular and morphological approach. Journal of Evolutionary Biology 20: 403-414.

Feulner PGD, Kirschbaum F, Schugardt C, Ketmaier V, Tiedemann R. 2006. Electrophysiological and molecular genetic evidence for sympatrically occurring cryptic species in African weakly electric fishes (Teleostei: Mormyridae: Campylomormyrus). Molecular Phylogenetics and Evolution 39: 198-208.

Fowler HW. 1934. Fishes obtained by Mr. H. W. Bell-Marley chiefly in Natal and Zululand in 1929 to 1932. Proceedings of the Academy of Natural Sciences of Philadelphia 86: 405-514.

Fricke R, Eschmeyer WN. n.d. Guide to fish collections. Available at http://researcharchive.calacademy.org/research/ichthyology/ catalog/collections.asp [accessed 12 February 2016].

Gilchrist JDF, Thompson WW. 1913. The freshwater fishes of South Africa. Annals of the South African Museum 11: 321-463.

Kensley B. 1970. Some decapod Crustacea from northern South West Africa, including a new species of Hippolyte. Cimbebasia, Series A, Natuurwetenskappe 1: 179-188.

Kramer B. 1990. Electrocommunication in teleost fishes: behavior and experiments. Berlin: Springer-Verlag.

Kramer B. 1996. Electroreception and communication in fishes. Stuttgart, Jena, Lübeck, Ulm: Gustav Fischer Verlag.

Kramer B. 1997. A field study of African elephantfish (Mormyridae, Teleostei): electric organ discharges in Marcusenius macrolepidotus (Peters, 1852) and Petrocephalus catostoma (Günther, 1866) as related to sex. Journal of African Zoology 111: 313-341.

Kramer B. 2013a. Differentiation in morphology and electrical signalling in four species of para- and sympatric Marcusenius (Teleostei: Mormyridae) from Côte d'Ivoire, West Africa. Marine and Freshwater Behaviour and Physiology 46: 105-133.

Kramer B. 2013b. A morphological study on species of African Mormyrus (Teleostei: Mormyridae) and their electric organ discharges. African Journal of Aquatic Science 38: 1-19.

Kramer B. 2013c. Morphological and electrophysiological field observations on electric freshwater fish of the genus Mormyrops Müller, 1843 (Actinopterygii: Teleostei: Mormyridae) from West and southern Africa. African Journal of Aquatic Science 38(Suppl.): 31-41.

Kramer B, Skelton P, van der Bank H, Wink M. 2007. Allopatric differentiation in the Marcusenius macrolepidotus species complex in southern and eastern Africa: the resurrection of $M$. pongolensis and $M$. angolensis, and the description of two new species (Mormyridae, Teleostei). Journal of Natural History 41: 647-708.

Kramer B, Swartz ER. 2010. A new species of slender stonebasher within the Hippopotamyrus ansorgii complex from the Cunene River in southern Africa (Teleostei: Mormyriformes). Journal of Natural History 44: 2213-2242.

Kramer B, van der Bank FH. 2000. The southern churchill, Petrocephalus wesselsi, a new species of mormyrid from South Africa defined by electric organ discharges, genetics, and morphology. Environmental Biology of Fishes 59: 393-413.

Kramer B, van der Bank H, Flint N, Sauer-Gürth H, Wink M. 2003. Evidence for parapatric speciation in the mormyrid fish, Pollimyrus castelnaui (Boulenger, 1911), from the Okavango Upper Zambezi River systems: P. marianne sp. nov., defined by electric organ discharges, morphology and genetics. Environmental Biology of Fishes 67: 47-70.

Kramer B, van der Bank FH, Wink M. 2004. The Hippopotamyrus ansorgii species complex in the Upper Zambezi River system, with a description of a new species, $\mathrm{H}$. szaboi (Mormyridae). Zoologica Scripta 33: 1-18.

Kramer B, van der Bank FH, Wink M. 2014. Marked differentiation in a new species of dwarf stonebasher, Pollimyrus cuandoensis sp. nov. (Mormyridae, Teleostei), from a contact zone with two 
sibling species of the Okavango and Zambezi Rivers. Journal of Natural History 48: 429-463.

Kramer B, Westby GWM. 1985. No sex difference in the waveform of the pulse type electric fish, Gnathonemus petersii (Mormyridae). Experientia 41: 1530-1531.

Kramer B, Wink M. 2013. East-west differentiation in the Marcusenius macrolepidotus species complex in southern Africa: the description of a new species for the Cunene River, Namibia (Mormyridae, Teleostei). Journal of Natural History 47: 2327-2362.

Lavoué S. 2012. Petrocephalus Marcusen, 1854 (Osteoglossomorpha: Mormyridae) of the Bangweulu-Mweru ecoregion (Luapula River system, Congo basin), with the description of a new species. Journal of Natural History 46: 2159-2178.

Lavoué S, Bigorne R, Lecointre G, Agnèse J-F. 2000. Phylogenetic relationships of mormyrid electric fishes (Mormyridae; Teleostei) inferred from cytochrome $b$ sequences. Molecular Phylogenetics and Evolution 14: 1-10.

Lavoué S, Sullivan JP. 2004. Simultaneous analysis of five molecular markers provides a well-supported phylogenetic hypothesis for the living bony-tongue fishes (Osteoglossomomorpha: Teleostei). Molecular Phylogenetics and Evolution 33: 171-185.

Lavoué S, Sullivan JP. 2014. Petrocephalus boboto and Petrocephalus arnegardi, two new species of African electric fish (Osteoglossomorpha, Mormyridae) from the Congo River basin. ZooKeys 400: 43-65.

Lawal-Are AO, Owolabi AT. 2012. Comparative biology of the prawns Macrobrachium macrobrachion (Herklots) and Macrobrachium vollenhovenii (Herklots) from two interconnecting fresh/brackish water lagoons in south-west Nigeria. Journal of Marine Science: Research \& Development 2: 108. 8 pp.

Maake PA, Gon O, Swartz ER. 2014. Description of three new species of Marcusenius Gill 1862 (Teleostei: Mormyridae) from South Africa and Mozambique. Zootaxa 3780: 455-480.

McGarigal K, Cushman S, Stafford S. 2000. Multivariate statistics for wildlife and ecology research. New York: Springer Verlag.

Moller P. 1995. Electric fishes: history and behavior. London: Chapman \& Hall.

Moore AE, Larkin PA. 2001. Drainage evolution in south-central Africa since the breakup of Gondwana. South African Journal of Geology 104: 47-68.

Moritz T, Engelmann J, Linsenmair KE, von der Emde G. 2009. The electric organ discharges of the Petrocephalus species (Teleostei: Mormyridae) of the Upper Volta system. Journal of Fish Biology 74: 54-76.

Paugy D. 2002. Reproductive strategies of fishes in a tropical temporary stream of the Upper Senegal basin: Baoulé River in Mali. Aquatic Living Resources 15: 25-33.
Scheffel A, Kramer B. 1997. Electrocommunication and social behaviour in Marcusenius senegalensis (Mormyridae, Teleostei). Ethology 103: 404-420.

Skelton PH. 1993. A complete guide to the freshwater fishes of southern Africa. Halfway House (South Africa): Southern Book Publishers.

Skelton PH. 1994. Diversity and distribution of freshwater fishes in East and southern Africa. Musée Royal de l'Afrique Centrale Tervuren, Belgique: Annales - Série in- $8^{\circ}$ - Sciences Zoologiques $275: 95-131$.

Skelton $\mathrm{P}[\mathrm{H}]$. 2001. A complete guide to the freshwater fishes of southern Africa (2nd edn). Cape Town: Struik.

Sullivan JP, Lavoué S, Arnegard ME, Hopkins CD. 2004. AFLPs resolve phylogeny and reveal mitochondrial introgression within a species flock of African electric fish (Mormyroidea: Teleostei). Evolution 58: 825-841.

Sullivan JP, Lavoué S, Hopkins CD. 2000. Molecular systematics of the African electric fishes (Mormyroidea: Teleostei) and a model for the evolution of their electric organs. Journal of Experimental Biology 203: 665-683.

Sullivan JP, Lavoué S, Hopkins CD. 2002. Discovery and phylogenetic analysis of a riverine species flock of African electric fishes (Mormyridae: Teleostei). Evolution 56: 597-616.

Tabachnick BG, Fidell LS. 2013. Using multivariate statistics. Boston: Pearson.

Tamura K, Stecher G, Peterson D, Filipski A, Kumar S. 2013. MEGA6: Molecular evolutionary genetics analysis version 6.0. Molecular Biology and Evolution 30: 2725-2729.

Taverne L. 1971. Note sur la systématique des poissons Mormyriformes. Le problème des genres Gnathonemus Gill, Marcusenius Gill, Hippopotamyrus Pappenheim, Cyphomyrus Myers et les nouveaux genres Pollimyrus et Brienomyrus. Revue de Zoologie et de Botanique Africaines 84: 99-110.

van der Bank FH, Greenfield R, Daru BH, Yessoufou K. 2012. DNA barcoding reveals micro-evolutionary changes and river systemlevel phylogeographic resolution of African silver catfish Schilbe intermedius (Actinopterygii: Siluriformes: Schilbeidae) from seven populations across different African river systems. Acta Ichthyologica et Piscatoria 42: 307-320.

van der Bank FH, Kramer B. 1996. Phylogenetic relationships between eight African species of mormyriform fish (Teleostei, Osteichthyes): resolution of a cryptic species, and reinstatement of Cyphomyrus Myers, 1960. Biochemical Systematics and Ecology 24: 275-290.

Wiltschko W, Kramer B. 2009. Magnetic and electric senses. In: Binder MD, Hirokawa N, Windhorst U (eds), Encyclopedia of Neuroscience. Berlin: Springer Verlag. pp 2198-2206. 


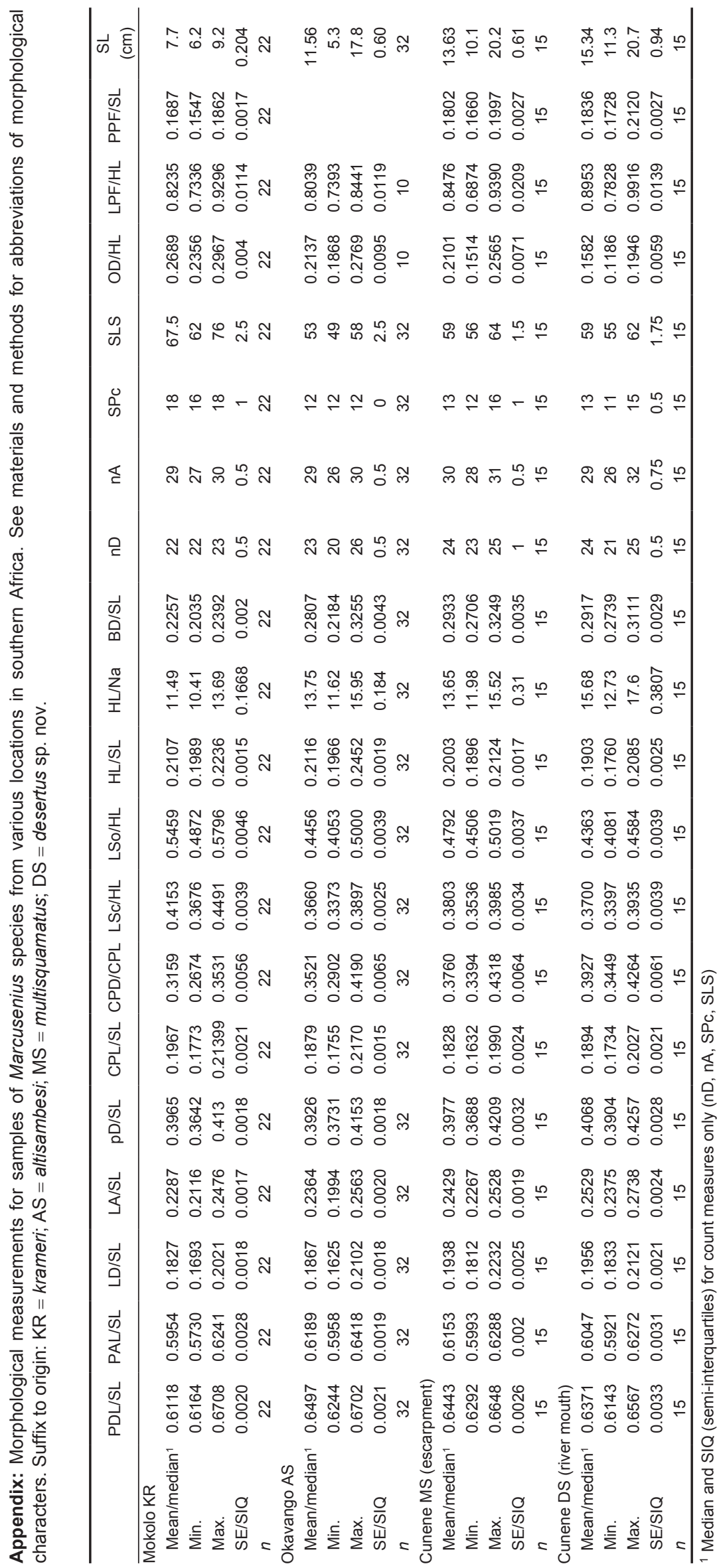


LB Kramer, FH van der Bank and M Wink

Marcusenius desertus sp. nov. (Teleostei: Mormyridae), a mormyrid fish from the Namib desert African Journal of Aquatic Science 2016: 18 pp; DOI: 10.2989/16085914.2015.1137855

Table S1: Other fish species collected from the Cunene River mouth (* denotes marine/backwater/brackish water). Collection method: $1=90 \mathrm{~mm}$ stretched mesh gillnets; $2=$ $40 \mathrm{~mm}$ stretched mesh gillnets; 3 = fyke or tunnel nets; 4 = hook-and-line; $5=$ castnets

\begin{tabular}{llll}
\hline Species & Common name & Authority & $\begin{array}{l}\text { Collection } \\
\text { method }\end{array}$ \\
\hline *Arius latiscutatus & Rough-head sea catfish & Günther, 1864 & 1 \\
Barbus matozzi & Papermouth & Guimaraes, 1884 & 3 \\
B. trimaculatus & Threespot barb & Peters, 1852 & 3,5 \\
Coptodon rendalli & Redbreast tilapia & (Boulenger, 1896) & $1,2,5$ \\
Glossogobius callidus ${ }^{1}$ & River goby & (Smith, 1973) & 3 \\
Labeo ansorgii & Cunene labeo & Boulenger, 1907 & 1,4 \\
Micralestes acutidens & Silver robber & (Peters, 1852) & 3,5 \\
Mormyrus lacerda & Western bottlenose & Castelnau, 1861 & 1 \\
$*$ Mugil cephalus & Flathead grey mullet & Linnaeus, 1758 & 4 \\
Oreochromis andersonii & Threespot tilapia & (Castelnau, 1861) & 1 \\
O. macrochir & Greenhead tilapia & (Boulenger, 1912) & 1,5 \\
Pomadasys jubelini & Atlantic spotted grunter & (Cuvier, 1830) & 5 \\
Sargochromis coulteri & Cunene bream & (Bell-Cross, 1975) & 2,5 \\
Schilbe intermedius & Silver catfish & Rüppell, 1832 & $1-5$ \\
Thoracochromis buysi & Namib river bream & (Penrith, 1970) & 2,4 \\
Tilapia sparrmanii & Banded tilapia & A Smith, 1840 & 3,5 \\
\hline
\end{tabular}

\footnotetext{
${ }^{1}$ First occurrence reported for the Cunene River (Barcode Of Life Database, iBOLD Process ID numbers: HVDBF248-11, 253-11 and 265-11)

${ }^{2}$ ZSM 43812
} 
Table S2: The first seven principal components on correlations for morphological characters of four Marcusenius samples from various locations in southern Africa $(N=84)$

\begin{tabular}{lrrrrrrr}
\hline Eigenvalue & 6.4787 & 3.6116 & 1.7010 & 0.9544 & 0.6557 & 0.5451 & 0.4928 \\
Percent & 40.492 & 22.573 & 10.631 & 5.965 & 4.098 & 3.407 & 3.080 \\
Cum. percent & 40.492 & 63.065 & 73.696 & 79.661 & 83.759 & 87.166 & 90.246
\end{tabular}

Component loadings

\begin{tabular}{lrrrrrrr} 
& PC1 & PC2 & PC3 & PC4 & \multicolumn{1}{c}{ PC5 } & \multicolumn{1}{c}{ PC6 } & \multicolumn{1}{c}{ PC7 } \\
PDL/SL & 0.10326 & -0.81324 & 0.37973 & -0.13936 & -0.07874 & 0.26919 & -0.00486 \\
PAL/SL & 0.55376 & -0.71398 & 0.21356 & -0.00803 & -0.02899 & 0.22235 & 0.03661 \\
LD/SL & 0.62665 & 0.54262 & 0.09627 & -0.22022 & 0.39527 & 0.14404 & 0.08479 \\
LA/SL & 0.72277 & 0.49382 & 0.10724 & -0.25064 & -0.00223 & -0.05348 & -0.16849 \\
pD/SL & 0.12664 & 0.77769 & -0.41008 & -0.09085 & 0.23086 & 0.20474 & 0.10927 \\
CPL/SL & -0.62106 & 0.18500 & -0.60386 & 0.06407 & -0.24136 & 0.23261 & -0.05091 \\
CPD/CPL & 0.78878 & 0.03092 & 0.36776 & -0.23911 & -0.03613 & -0.23044 & 0.13550 \\
LSo/HL & -0.86643 & 0.15513 & 0.36665 & 0.07947 & 0.02080 & 0.12386 & 0.09758 \\
LSc/HL & -0.76623 & 0.27219 & 0.35984 & 0.04741 & -0.06785 & 0.12081 & 0.19789 \\
HL/SL & -0.43714 & -0.60617 & -0.04922 & 0.29971 & 0.49233 & -0.14624 & 0.12262 \\
HL/Na & 0.75181 & 0.15004 & -0.12792 & 0.20948 & -0.30117 & -0.25377 & 0.26899 \\
BD/SL & 0.89371 & -0.09433 & 0.04583 & -0.04957 & -0.02582 & 0.31052 & 0.01275 \\
nD & 0.45973 & 0.50126 & 0.26246 & 0.49255 & -0.08303 & 0.17009 & 0.28806 \\
nA & 0.33655 & 0.44655 & 0.41664 & 0.52379 & 0.05033 & 0.00760 & -0.44299 \\
SPc & -0.73833 & 0.35648 & 0.43198 & -0.17690 & 0.04866 & -0.09634 & 0.06592 \\
SLS & -0.67811 & 0.43300 & 0.32932 & -0.24711 & -0.17013 & 0.00720 & -0.05607 \\
\hline
\end{tabular}

Cunene River (escarpment specimens, $n=15$ ): M. multisquamatus; Cunene River mouth specimens $(n=15)$ : $M$. desertus sp. nov.; Okavango $(n=32)$ : M. altisambesi; Mokolo River $(n=22)$ : M. krameri 